University of Wollongong

Research Online

Faculty of Social Sciences - Papers (Archive) Faculty of Arts, Social Sciences \& Humanities

2010

Neoliberalism and the biophysical environment: a synthesis and evaluation of the research

Noel Castree

University of Wollongong, ncastree@uow.edu.au

Follow this and additional works at: https://ro.uow.edu.au/sspapers

Part of the Education Commons, and the Social and Behavioral Sciences Commons

Research Online is the open access institutional repository for the University of Wollongong. For further information contact the UOW Library: research-pubs@uow.edu.au 


\title{
Neoliberalism and the biophysical environment: a synthesis and evaluation of the research
}

\begin{abstract}
This article both synthesizes and critically evaluates a now large, multi-disciplinary body of published research that examines the neoliberalization of environmental regulation, management, and governance. Since the late 1970s, neoliberal ideas and ideals have gradually made their way into the domain of environmental policy as part of a wider change in the global political economy. While the volume of empirical research is now such that we can draw some conclusions about this policy shift, the fact that the research has evolved piecemeal across so many different disciplines has made identifying points of similarity and difference in the findings more difficult. After clarifying what neoliberalism is and explaining why the term 'neoliberalization' is preferable, the article analyzes the principal components and enumerates the social and environmental effects of this multifaceted process. By offering a comprehensive and probing survey of the salient literature, I hope not only to codify the existing research but also to guide future critical inquiries into neoliberal environmental policy.
\end{abstract}

\section{Keywords}

environment, research, biophysical, evaluation, neoliberalism, synthesis

\section{Disciplines}

Education | Social and Behavioral Sciences

\section{Publication Details}

Castree, N. (2010). Neoliberalism and the biophysical environment: a synthesis and evaluation of the research. Environment and Society: advances in research, 1 (1), 5-45. 


\title{
Neoliberalism and the biophysical environment: a synthesis and evaluation of the research
}

\begin{abstract}
This essay both synthesises and critically evaluates a now large, multidisciplinary body of published research which examines the 'neoliberalisation' of environmental regulation, management and governance. From the late 1970s, neoliberal ideas and ideals gradually made their way into the domain of environmental policy as part of a wider - though geographically uneven change in the global political economy. The volume of theoretically-informed empirical research is now such that we can draw some conclusions about the nature and effects of this widespread policy shift. However, because the research is spread across so many different social science disciplines and has evolved piecemeal, identifying points of similarity and difference in the findings is no mean feat. After clarifying what 'neoliberalism' is and suggesting why the process-term 'neoliberalisation' is preferable, the essay proceeds in four stages. First, the neoliberalisation of environmental regulation, management and governance is disaggregated into seven principal components. Second, the various social and environmental effects of this multi-faceted process are enumerated. Third, several 'take home' lessons about both process and effects are identified. Finally, the essay asks some critical questions about the way researchers have interrogated nature's neoliberalisation thus far. By offering a comprehensive and probing survey of the salient literature, I hope not only to codify the existing research but to steer future critical inquiries into neoliberal environmental policy - indeed, into environmental policy of whatever stripe.
\end{abstract}




\title{
Neoliberalism and the biophysical environment: a synthesis and evaluation of the research
}

\author{
Noel Castree, School of Environment and Development, Manchester University, \\ ENGLAND, M13 9PL noel.castree@man.ac.uk
}

\section{Introduction}

In this essay I will examine the relationship between neoliberalism and the biophysical world. 'Neoliberalism' is very much a critics' term, an oppositional badge as much as an analytical concept. ${ }^{1}$ For those who choose to use it, the word describes a worldview made flesh over the last 30 years at the subnational, national and global scales. Rarely invoked before 2000, it is now part of the lingua franca of left-wing social scientists and activists. Researchers in development studies, sociology, area studies, anthropology, labor studies, political science, cultural studies, human geography, philosophy, environmental studies, international relations, education policy studies, and the radical fringes of the economics profession have - over the last decade - sought to define neoliberalism, identify its modes of operation, track its mutations, pin-point its effects, and describe various modes of opposition to it. Where political activists have often used the term for polemical purposes, academic researchers have attempted to mount a rather cooler challenge to neoliberalism on both evidential and moral-political grounds. There have been two main camps, theoretically-speaking: namely, a political economic one (which is broadly neoMarxist) and a Foucauldian one - with some overlap between the two (e.g. Lockwood \& Davidson, 2009). ${ }^{2}$ Together, their members have produced a now sizeable literature comprising monographs, coauthored books, edited collections and peer review papers like this one. I will survey this literature, focussing on those parts of it where neoliberal environmental use and management has been principal focus of analytical attention. Note that I have only selected publications in which the term 'neoliberalism' is - in my view - central to the arguments and research findings presented. ${ }^{3}$

\footnotetext{
${ }^{1}$ It initially gained popularity in left-wing circles in Latin America, as a reaction to the market-led reform agenda of General Pinochet in Chile.

2The latter are sometimes given to calling neoliberalism 'advanced liberalism'. In the former case, Karl Polanyi's economic history is used by some in conjunction with Marx's late political economic writings because of Polanyi's critique of the 'classic liberalism' of the $19^{\text {th }}$ and early $20^{\text {th }}$ centuries. Others call upon Antonio Gramsci's ideas in order to get a handle on whether and how neoliberal values and practices get embedded in everyday life outside the formal spheres of 'state' and 'economy'. Few authors whose work is reviewed here have used all of Marx, Polanyi and Gramsci together in a substantive way. Typically one or two of these theorists' ideas are used (usually selectively) in any given study. I say more about this in the penultimate section of the paper. Some authors in the political-economy fold have drawn upon other theorists - such as Jean Baudrillard and Jim O'Connor - but, currently, Marx, Polanyi and Gramsci seem to be the favoured ones.

3In other words - and for better or worse - I have not included publications in which environmental use and management have been analysed in the context of policy changes that some would say are 'neoliberal' - such as 'structural adjustment policy' in the global South in the 1980s and 90s. Unless
} 
The original architects of neoliberal thinking, such as Milton Friedman and Friedrich von Hayek, said little about environmental issues or natural resource management. However, since the mid-1980s, many neoliberal values and principles have steadily made their way into the domain of environmental policy ${ }^{4}$ - conceived here in the widest possible sense, to include situations where any element of the biophysical world is a major focus of policy makers' attention at any spatio-temporal scale. Accordingly, a previous trickle of research into neoliberal environmental governance has given way to something of a torrent over the last five years or so. As we'll see, this research comprises predominantly single-site case studies, presented in rich empirical detail. It also cover the full spectrum of environmental and resource policy domains, from water to fisheries to farming and beyond. To date, this research has grown organically in a rather piece-meal fashion, with some elements - though only some - of disciplinary cross-over. ${ }^{5}$ In order to steer its future development, it is useful to take-stock of the insights the research offers to-date and to draw wider lessons - both about neoliberal environmental governance but also, as I will explain, about the way critics' have investigated it so far.

To summarise, this essay will operate at two levels towards two rather different ends. It will parse the insights of numerous studies in order to clarify how neoliberal environmental governance has operated to-date, and with what effects. But secondly, it will also treat the authors of these studies as a loose 'epistemic community' whose worldview and research practices do not simply hold a mirror up to a neoliberal world existing 'out there'. I identify broadly with its members' value-set and normative agendas, but I also believe that this community may want to reflect critically on its own habits of thought and analysis. Having written along these lines for a human geography readership (Castree, 2008a, 2008b), this essay is directed at a wider and more intellectually mixed audience spanning several social science disciplines (as befits the remit of

authors discuss neoliberalism explicitly, I have excluded their publications - even when these publications discuss related matters such as the privatisation of environmental goods and services. ${ }^{4}$ In part, this reflects the nature of many environmental goods and services: they inevitably impinge upon, or are themselves affected by, ostensibly 'non-environmental' policy domains (such as international trade policy). But it also reflects two other things. First, many environmental goods and services are of great social and economic importance (water and sewerage being prime examples). It is no surprise, therefore, that neoliberal reformers were intent on altering their modes of delivery and governance, for they were hardly marginal to any project of remaking economy, state and society tout court. Secondly, a set of worrying environmental problems already evident in the 1960s have subsequently grown in number, diversity and seriousness. Neoliberal policy makers have sought to address these problems in ways consistent with their particular worldview. The terms 'free market environmentalism', 'liberal environmentalism', 'green capitalism', 'ecological modernisation', 'green neoliberalism' and 'ecological capitalism' all capture, with rather different cognitive and normative valences, this explicit problem-solving agenda.

${ }^{5}$ For instance, researchers in geography, anthropology and development studies have drawn upon each other's research of late when thinking through new developments in nature conservation. For example, see the recent special issue of the journal Antipode (2010). 
this journal). ${ }^{6}$ I hope that those who are new to the subject, but also those familiar with it, will profit similarly from reading this (so I hope) comprehensive review. ${ }^{7}$ As ever with review essays, there is the risk that I am imposing a false order on the literature I survey. I will thus try to be scrupulous about justifying my various 'moves' as I proceed, and I invite readers to assess these moves critically.

The essay is organized as follows. I begin in a rather obvious place by seeking to define and delimit 'neoliberalism'. Here I summarise the insights of critical social scientists who do not themselves study environmental management, but whose writings have influenced those who do. Then I introduce the research literature on nature's neoliberalisation in general terms. This done, the next two sections distil the substantive insights of this largely case-study based literature, focussing on the process of re-regulation and its socio-ecological outcomes respectively. I then further distil these insights into a small set of provisional 'take home' lessons. The final main section presents a sympathetic critique of the literature. In this penultimate part I raise several key questions about the published research bracketed earlier in the essay. A warning: the essay is unusually long and is thus best digested in at least two sittings (starting with this introduction and the next two sections). At the considerable risk of sounding self-indulgent I believe the length is justified: the size of the literature reviewed, plus the scope of my 'take' on it, mean that a shorter survey would sacrifice much detail and many key points - especially for those new to this literature.

Before I get down to business, I should make one final introductory observation. In light of the recent financial crisis and current global economic recession, some have suggested that the 'neoliberal era' has come to an end (or at least the beginning of the end). If true, this suggestion would imply no future for the sort of research surveyed here, and would make this essay very untimely indeed. Needless to say, I reject this suggestion (cf. Brand and Sekler, 2009). Periodising history is notoriously tricky, so too is the identification of temporal

\footnotetext{
${ }^{6}$ There is also a good review by Himley (2008) in the online journal Geography Compass. I have three student-orientated essays on neoliberalism and nature in the same journal (Castree 2010a, b \& c). Because I am presuming little prior knowledge of at least some readers, this essay inevitably recapitulates ideas presented in my back-to-back 2008 EPA essays. However, knowledgeable readers will, I hope, see the 'value added' in the present essay compared to the two earlier ones - not least my attempt to cast my net wider and encompass work published in several disciplines outside by 'home base' of geography.

${ }^{7}$ Inevitably, I have missed some things, despite my attempt to be thorough. For instance, a recent special issue of the journal Review of Radical Political Economics (2010) focussing on water service privatisation, was published as this essay went to press. As stated in note 3 above, absences like this one raise the wider question of how far I should have thrown my net when researching this essay. My rule of thumb was only to read those studies in which the term 'neoliberalism' was used in a morethan-passing way. However, this means that numerous studies focussed on things like 'markets' and 'privatization', yet where neoliberalism receives no mention, were not included in this review. Note that I only reference studies that are published, and have gone through peer review, rather than working papers or conference papers as well.
} 
'breaks'. As Craig and Cotterell (2007: 510) note, “... the various conjunctural factors bundled together [by analysts] to constitute 'neoliberalism' (and any plausible period shift in it) are quite diverse in nature, so that first of all comparing the relative weight or importance of any them to an overall periodising assessment is analytically fraught". Moreover, even supposing that we have been living through an historic period sufficiently homogenous to be called 'neoliberal', experience tells us that there are rarely punctual transitions between one putative 'era' and another. The traces of the recent past will inevitably continue to affect both the present and the short-to-medium term future (see Brenner et al., 2010). As New Left Review editor Susan Watkins notes, "The widely proclaimed end of neo-liberalism looks more and more like the continuation of its agenda by other means" (2010: 14). I doubt, in other words, that the term 'neoliberalism' will disappear from social scientists' (or political activists') vocabulary any time soon. If it does, we will probably be employing new words to capture its meanings and to describe many of its real world objects (Clarke, 2010). Therefore, throughout this essay I will talk of neoliberalism in the present tense, thus presuming that the term and the things it names retain their currency for the time being. ${ }^{8}$ The question then becomes not whether we should (still) use the term but how.

\section{What is 'neoliberalism'? \\ Conceptual issues}

The research into neoliberal environmental governance is in one sense parasitic on a wider theoretical and empirical literature in which environmental issues are not strongly thematised. This broader literature mostly predates the research being surveyed in this essay, and this antecedence explains why it has proven formative for many who interrogate neoliberal environmental policy. There has, in my view, been a tendency for the latter to borrow definitions and insights from the former rather than to rework and question them. That does not make their work entirely derivative - far from it in fact. As we will see later, the primarily empirical (rather than theoretical) character of recent research into neoliberal environmental governance is its major strength and contribution. Writing as recently as 2006, Jamie Peck - who, with Adam Tickell, Nik Theodore and Neil Brenner has done much to shape social scientific conceptions of 'neoliberalism' - observed that 'there remains a paucity of 'grounded' work on the specific and concrete routines, practices, networks, and structures through which the neoliberal project has been constructed and sustained" (p. 731). This is no longer true, and the recently published research into neoliberalism and the environment can take considerable credit for filling the empirical gap that Peck identified. Even so, in conceptual terms much of

${ }^{8} \mathrm{I}$ am in good company. There was recently a 3-day workshop at Lund University in Sweden, where many researchers assembled to present research pertaining to the topic 'A Brief Environmental History of Neoliberalism'. Go to http://www.worldecologyresearch.org to download the papers presented at this meeting. 
this research has tended to work with 'off the peg' definitions of neoliberalism developed by others (such as Peck himself). What is more, these definitions have been used selectively and partially, depending on the case.

Note that I use the term definitions in the plural. The reason that economic sociologist Stephanie Mudge (2008) so recently felt compelled to ask 'What is neoliberalism?' is because of the diversity of meanings and applications in-play. Despite the term's current popularity among a cohort of left-wing social scientists, the more familiar it's become, the less consensus there appears to be about what it means. As James Ferguson observes, "there is [now] huge variation in the way the word 'neoliberalism' is used in contemporary scholarship" (2010: 170). And yet, perhaps curiously, most researchers who use the term typically proceed as if the meaning is clear and maps onto a definite set of values, ideas and/or practices existing in the wider world. There has thus far been little sustained discussion of the term's ambiguities and complexities, but this is now certainly overdue.

So what is going on here? One view is that neoliberalism is an unusually complex word (like 'globalisation' or 'nature') such that it signifies a range of related meanings which themselves can be applied to a plethora of real-world referents. Seen from this perspective, as long as the term's meaning is clear for each context of application there is no especial problem with it signifying several things and having myriad objects of empirical reference - so long as they have strong 'family ties'. Another view is that we should relieve the term of some of its current denotations, not least because we have other well-established words for them - such as privatisation, commodification, the 'free market', 'the Washington Consensus' or structural adjustment. By doing so, we would restrict - and so render more precise - the meaning of those situations or things we still prefer to describe as neoliberal (see Boas and Gans-Morse, 2009). Still another perspective is that we are now beyond the point of no return: so various and confusing are the meanings of 'neoliberalism' that it has become as 'chaotic' a concept as globalization was after a decade of debate and use (circa 1990-2000). For instance, in their recent review, the anthropologists Catherine Kingfisher and Jeff Maskovsky confessed a temptation "to abandon the term altogether" (2008: 123) - and they are not alone (see also Barnett, 2009).

For now, I will adopt the first of these viewpoints (though I will come back to the other two towards the end of this essay). In other words, I will presume that while the term 'neoliberalism' is both polysemic and refers to a plurality of material and discursive things, there are nonetheless a set of fairly stable, circumscribed but also related meanings in use that are applied in a relatively consistent way by academic analysts. In effect, this is the viewpoint adopted by those social scientists investigating neoliberalism and the biophysical world (as we'll see later). Each researcher has defined neoliberalism in a certain recognised manner, and then undertaken an empirical investigation of environmental governance with their particular definition in place. The 
assumption is that there is a meaningful similarity (or even relationship) between otherwise different, separate studies.

\section{The meanings of neoliberalism}

As some readers will know, the term 'neoliberalism' was coined by a group of economists and legal scholars based in Frieburg between the first and second world wars. Subsequently, it was used quite briefly by those now thought to be neoliberalism's principal intellectuals, the already mentioned von Hayek and Friedman - even though neither man entirely accepted the Frieburg (or 'ordoliberal') model of a state-managed 'market society'. As I intimated above, those individuals and institutions the critics choose to call 'neoliberals' did not/do not use the term as a self-descriptor and rarely ever have. After a smattering of appearances during the 1990s (e.g. Barry, Osborne and Rose, 1996; Fraser, 1993; Gowan, 1995; Tickell and Peck, 1995), these critics started to invoke the term with increasingly frequency from the turn of the millennium. My own reading of the now voluminous academic literature suggests that, for this interdisciplinary epistemic community of social scientists, 'neoliberalism' describes one or more of the following three related things: namely, a worldview (i.e. a body of normative principles, goals and aspirations amounting to a philosophy of life, or something close to one); a policy discourse (i.e. a set of specific values, norms, ambitions and associated policy proposals professed by those who control, or realistically seek to control, the formal apparatuses of government); and a set of practical policies (i.e. concrete regulations and procedures that make both the worldview and the policy discourse flesh in some tangible way). As a short-hand, we can think in terms of the 'three ps': philosophy, program and practice. ${ }^{9}$ I will take each of neoliberalism's three aspects in turn.

\section{Neoliberalism as worldview (philosophy)} According to Harvey (2007: 24), though von Hayek, Friedman and others of their ilk rarely used the term, their neoliberalism "took the political ideals of individual liberty and freedom as sacrosanct". However, there are many different ways in which to define and engender liberty and freedom. ${ }^{10}$ The

\footnotetext{
${ }^{9}$ In all cases a leit-motif is more-or-less far reaching change, which is why neoliberalism has been commonly described using action-terms like 'project', 'strategy', 'roll-back', 'roll-out' and 'regime change'. It is understood by the critics to pose a definite challenge to what has heretofore constituted 'common sense' discourse and practice in the domains of state, economy and society. This strongly performative element leads David Harvey (2007) to regard neoliberalism as a synonym for 'creative destruction' - that signature element of capitalist modernity in all its geographically and historically varied forms.

${ }^{10}$ Modern liberal philosophy is a diverse and complex thing. Not all self-declared 'liberals' could be fairly described as 'neoliberals' in the sense meant by critical social scientists or left-wing political activists. What's more, the neoliberal worldview is rather more radical than that of the Freibergers who originally claimed the term as their own. Indeed, some of the latter considered the likes of von Hayek to be 'palaeo-liberals', a pejorative reference to their aspirations for a world of laissez-faire writlarge.
} 
neoliberal ideals articulated in books such as The road to serfdom (von Hayek, 1944), The constitution of liberty (von Hayek, 1960) and Capitalism and freedom (Friedman, 1962) accented two things. First, the state's role was to maximise the independence of both real and institutional-juridical individuals: anything less would be anti-liberal, a travesty of 'true freedom'. Governments and bureaucracies, it was argued, should refrain from both imposing collective agendas and otherwise 'interfering' in the lives of people. In this sense, the early neoliberals strongly emphasised not only the rights of individuals but their responsibility to make their own way in the world. Second, neoliberalism's founding thinkers saw money-mediated markets as the best mechanism for coordinating among the diverse needs and wants of ostensibly free people. This is because markets were seen as highly 'intelligent', as well as 'efficient': price signals, it was claimed, enable disparate providers and users of goods and service to achieve many of their desires, given whatever restraints of resource availability happen to be in place for those involved. Indeed, market competition was seen as bringing the best out of entrepreneurs, while delivering to intermediate- and end-consumers value-for-money. This belief segued into a critique of 'state failure', which is the idea that government bureaucracies are administratively cumbersome and economically wasteful vehicles for service delivery. ${ }^{11}$

The neoliberal worldview, as summarised above, is not - despite appearances - fixated on economic liberty alone, even though it does emphasise it very strongly indeed. Political and civil liberty feature too, in that electoral democracy was the early neoliberals' favoured political system and freedom of expression (within or without the market) also seen as fundamentally important. This wide-ranging doctrine began to take shape during the second world war and its immediate aftermath. It was fashioned in reaction to the totalitarian impulses of fascism and communism, but also presented as an alternative to the new Keynesian welfare-state paradigm - which licensed state intervention in the market and in many aspects of citizens' daily lives. In the former respect neoliberal thinking was at one with the zeitgeist, but not in the latter respect. As Peck says of The road to serfdom, "the book may have been a best-seller, but it was practically an act of self-immolation for Hayek-the-economist" (2008: 5-6). After all, writing in the same year of its publication, Hayek's contemporary Karl Polanyi declared that "our age will be credited with having seen the end of the

\footnotetext{
${ }^{11}$ In this latter respect, the neoliberal worldview has frequently been called 'market triumphalist', 'market extremist' or 'free market capitalist'. More than any other institution in modern society, the market is seen as the hand-maiden of liberty and freedom by virtue of Adam Smith's famous 'hidden hand'. This also dovetailed with a belief that markets should, in many cases, substitute for decisions made within the domain of 'politics' currently. In other words, the likes of Friedman argued that the political sphere has, in some senses, become 'bloated' since world war two in many Western democracies. Bloated not just in the administrative-technical sense ('the big state', reliant on too much tax income and borrowing) but in the sense that too many private issues were being made into matters of public concern ('the nanny state', intruding into matters that should rightly be decided by individuals, families or communities).
} 
self-regulating market" (1944: 142). For this reason, the neoliberal worldview remained well outside the perimeter of cognitive and moral 'common sense' until the economic and political crises of the 1970s.

\section{Neoliberalism as policy discourse (program)}

For over three decades, neoliberal ideas were incubated in a select group of university economics departments, foundations and think tanks. As the excellent histories recounted by Peck (2008) and Mirowski \& Plehwe (2008) show so well, the neoliberal 'thought collective' was transnational, comprising groups in Europe and the US and with a good deal of interchange between them - not least because of the efforts of the Mont Pelerin Society (formed by von Hayek in 1947 and based in Chicago). Its eventual success was hardly predictable during the immediate post-1945 period. Lacking political influence and much academic credibility, neoliberal thinkers initially produced a combination of general manifestos and fundamental works of theory, only later turning their attention to policy programs in live settings. In the latter respect, Pinochet's Chile was a key opportunity, as a group of Friedman-trained economists were invited to remake the country's political and moral economy almost overnight (safeguarded by a military dictatorship). It was the first of several opportunities provided by domestic crises of one sort or another, but without the groundwork laid by the prolonged efforts of the Mont Pelerinians these opportunities could not have been exploited. As is well known, New Zealand, the United Kingdom and the United States were the other three countries where some version of the neoliberal worldview was taken seriously by political economic elites by the late 70s. Subsequently, it gained a hearing in many other countries (especially after the late 1980s 'revolutions' in eastern Europe) and also in a range of USdominated global institutions such as the World Bank and International Monetary Fund.

As a policy discourse, the neoliberal worldview is typically understood by critics to include the following seven proposals for significant society-wide change. Note that national governments are the major institutions tasked with delivering these changes - neoliberalism, like all political philosophies and programmes, is necessarily a state-led project.

- Privatisation: assigning clear, legally enforceable, private property rights to hitherto unowned, state owned or communally owned aspects of the social, cultural and/or natural worlds. ${ }^{12}$

- Marketisation: rendering alienable and exchangeable things that might not previously have been subject to a market logic expressed through

\footnotetext{
${ }^{12}$ In spatio-temporal terms, privatization typically amounts to geographical exclusion and the exclusion of current and future generations from use of, or the benefits of, a given portion of the biophysical world. All privatization are, at one and the same time, acts of inclusion and alienation, creating both entitlements and expulsions.
} 
commodity transactions within and between nation states measured in monetary terms. ${ }^{13}$

- State roll back or de regulation: the withdrawal or diminution of state intervention in certain areas of social, cultural and environmental life in order to enable firms and consumers to exercise 'freedom of choice'; the creation of new quasi-state or state-sanctioned 'non-political' actors to take-on functions that states themselves could otherwise perform in theory or practice; and contracting private or third sector bodies to deliver some state services through a process of competitive tendering or through partnership agreements.

- Market-friendly reregulation: a reconfiguration of the state so as to extend the frontiers of privatisation and marketisation. Here, then, the state in its various forms becomes 'market manager' and less of a 'provider' to the citizenry or 'special interests' therein: it intervenes for the msrket economy not, as it were, in it. This entails fiscal discipline, a focus on supply side investments, entrepreneur- and consumer-friendly tax policies, firmfriendly labour market policies, and measures to enable 'free' movements of money capital and also other less 'fluid' commodities.

- Use of market proxies in the residual state sector. making remaining state functions and services more market-like in their operation through the use of measures like internal markets, cost-recovery and budget-capping. This amount to embedding an ethos and the practices of 'commercialisation' into state services. ${ }^{14}$

- The strong encouragement of 'flanking mechanisms' in civil society: state-led measures to promote the growth of (i) robust informal and social economies, and (ii) voluntary, charitable, non-profit and community groups - all preferably well-funded and professionalised. Together these are intended to fill the vacuum created by the absence/diminution of direct state-support in the social and environmental domains. They could be said to comprise a 'shadow state' that is emergent organically once prodded by the state.

- The creation of 'free', 'self-sufficient' and self-governing individuals and communities: the cultivation of an ethic among persons, other juridical units, and communities that emphasises less, and ultimately limited, reliance on public services or state agencies for life's necessities. This ethic extends to those operating within the state apparatus itself, as per point 5 above. It equates to a 'responsibilization' of all producers, consumers, citizens,

\footnotetext{
${ }^{13}$ It's worth noting that, for many commentators, it is the conjunction of privatisation and marketisation that defines 'commodification'. Needless to say, in practice both privatisation and marketisation take a number of concrete forms as befits the particular commodities, firms, consumers and other relevant parties in question.

${ }^{14}$ In the West, the term 'new public management' has become a familiar descriptor for this process, which denotes a management paradigm emphasising value-for-money, budget-capping, cost-recovery and an aversion to deficit spending where possible.
} 
families, communities, institutions and spatial units of governance, so too their 'autonomization'. ${ }^{15}$

Clearly, there is a dialectical relationship between neoliberalism as worldview and as program. To the extent that the program gains traction and exerts influence within any given context, it not only lends legitimacy to the worldview but poses a barrier to its future removal by critics.

\section{Neoliberalism as a set of policy measures (practice)}

For any program to translate into actual policies its advocates first need to render their worldview legitimate. As Clarke (2004: 34) reminds us, "Politics is both a regime of truth (ruling out the irrational, marginal or unworkable ...) and a field in which ... some discourses [are allowed] to contend". Because the neoliberal worldview and policy program are so wide ranging and ambitious, it is no surprise that they can be - and have been - translated into a plurality of concrete policy measures. Some common practices have been identified by analysts of neoliberalism-in-action (even if they've frequently been honoured-inthe-breach). To be specific:

- Macro-economic policies which place controls on government borrowing, keep inflation low, place constraints on domestic money supply, keep taxation levels low, allow exchange rates to float, and allow interest rates to be market determined (or at least not governmentally determined).

- Industrial and business policies that (i) remove selective subsidies, trade barriers, investment barriers and ownership barriers and (ii) incentivise innovation, competition and entrepreneurial risk-taking. In effect, these policies widen and intensify commercial competition.

- Labour market policies that remove collectivist 'obstacles' to competition and reward, such as wage controls and trade union membership.

- Education and training policies that focus on the supply side and encourage individuals to build their 'human capital', be adaptable and commit to 'lifelong learning'.

\footnotetext{
${ }^{15}$ What makes this policy discourse 'neo' (new) liberal - when compared with the so-called 'classical liberalism' of Adam Smith - is three things. First, from the 70s it was presented as an explicit critique of post-war 'managed capitalism', be it in parts of the former communist bloc, the Western social democracies or the many 'developmental states' of the global South. Secondly, it takes a fairly dim view of the state, public goods and common resources - except insofar as any of them can aid the cause of individual freedom or liberty. In Colin Crouch's words, "Not only is the state seen as having no ... modus operandi different from those of market actors, but it is seen to gain by subordinating it activities ... to such actors" (2004: 248). Finally, it has travelled far and wide geographically courtesy of various institutions and networks in which US neoliberals have played a highly active role (for more see Peck, 2010).
} 
- Managing, monitoring and audit measures that - whether in the private, state and third sectors - focus hard on setting targets, establishing benchmarks, measuring performance, penalising failure, and rewarding success. In the state sector the measures have been inspired, variously, by the approaches known as the 'new public management', 'transactions cost theory', and 'principal agent theory'.

- Social policies orientated to 'workfare' not 'welfare', and which offer state support only to the very needy or chronically disadvantaged. This entails a remoralisation of the poor and 'excluded' so as 'responsibilise' them for their livelihoods, their successes and their 'failures'. They are thus exposed to the various risks of life and living without much insurance offered by society or state.

- Law and order policies that take an uncompromising approach to rule-breakers, 'troublemakers' and those otherwise causing social disruption and infringing the rights of others.

- Civil rights policies that encourage free speech, freedom of information, lifestyle choice, privacy rights, and freedom of assembly - so long as the rule of law is observed.

- Governance policies that, in a range of policy areas, democratise and devolve decision-making by empowering a wide range of actors outside the formal sphere of 'government'. ${ }^{16}$ Empowerment is about making decisions and dealing with their consequences, for good or ill.

Note I will deal with environmental and natural resource policies later in the essay. For now, suffice to say that they aim to achieve given ends - such as environmental protection or resource conservation - in 'efficient' and 'competitive' ways by variously privatising, marketizing and de-statizing a range of biophysical goods and ecosystem services.

Again, it almost goes without saying that neoliberal policies are linked recursively to program and philosophy. For instance, Peck and Tickell (2002) have argued that the 'roll back' policies of a 'hard' neoliberal program have, in countries like Britain and the US, given way to 'roll out' policies that seek to embed core neoliberal principles and values as norms governing everyday life and living. A key point to make here is that a wide range of different concrete policy measures - alone and in combination - will 'deliver' various of the seven elements of the neoliberal policy programme detailed above. There is no universal or perfect 'one-to-one' mapping of these elements onto discrete policy measures.

\footnotetext{
${ }^{16}$ However, because many of these actors are unelected, many have regarded neoliberal policies as anti-democratic.
} 


\section{Neoliberalism or neoliberalizations?}

This three-part disaggregation of 'neoliberalism' usefully clarifies the term's complex meanings and myriad referents. It may help readers understand better what different researchers are referring to when they describe something as 'neoliberal'. Clearly, one should not elide philosophy, program or policies, even though they are necessarily related. Mudge (op. cit.), following sociologist Pierre Bourdieu's concept of different discursive-institutional 'fields', uses a 'horizontal' metaphor to understand the 'three ps'. For her, the worldview is located in the 'intellectual field' (dominated by university economics departments, think tanks and foundations), the program in the 'political field' (political parties, professional politicians and elected leaders), and the policies in the 'bureaucratic field' (civil servants, administrators, managers appointed by elected politicians, nominated firms, sanctioned NGOs and charities, etc). Obviously, the fields greatly overlap and mutually condition one another - but how?

Here, one or two commentators have come unstuck. For instance, in an uncharacteristically ill-judged - and much cited - observation, New Left Review editor Perry Anderson once said that "neoliberalism, as a set of principles, rules undivided across the globe $[\ldots]$ the most successful ideology in world history" (2000: 7). Similarly, someone otherwise attentive to the uneven development of neoliberalism, has sometimes described it using blanket metaphors:

"Neoliberal [ism] ... has in effect swept across the world like a vast tidal wave of institutional reform and discursive adjustment [...] no place can claim total immunity" (Harvey, op. cit. 23). Statements like these paint a picture of 'hegemonic neoliberalism', thus spatialising at the global scale the notion of a supposedly coherent period or era (the oft-used term 'neoliberalism globalization' performs the same function). They imply a one-way, unadulterated relationship between worldview, program and policies, in which a peculiarly homogenous geography of big- $\mathrm{N}$ neoliberalism writ-large is imagined - a sort of spreading ink-blot, beginning in the academic field. However, very few empirical analysts of neoliberalism see it in these simplistic terms, which is why the process-term neoliberalization has been favoured since it was coined nearly a decade ago by Peck and Tickell (2002). Neoliberalization describes an ongoing, unfinished process of proposing, revising, testing, applying and further altering neoliberal ideas and policies. As Neil Brenner and Nik Theodore (2002) have argued, 'actually existing neoliberalism' is not the same as the neoliberal worldview. Indeed, Harvey (2005: 19) regards the latter as utopian, the rhetorical cloak used to describe and justify the messy pragmatics of program and policies - it is thus ironic that he inadvertently bolsters the utopian rhetoric by discussing neoliberalism with a big -N.

These arguments suggest that what is called 'neoliberalism' in the singular is, in reality, a complex historical-geographical formation marked by unevenness and variety as much as by similarity: that is to say, a set of interconnected local, regional and national neoliberalizations in the plural. Neoliberal ideas may well have 'gone 
global' from the mid-1980s courtesy of the USA and its influence at the World Bank and IMF. But this has not comprised a tidy process of downward and outward diffusion from neoliberalism's North Atlantic heartlands. Instead, there has been path-dependency, contingent couplings, unplanned adaptations, organic mutations and a good deal of social resistance to new liberal policies. Varying combinations of coercion, consent, contestation and compromise describe the spatio-temporal evolution of neoliberal projects in different parts of the world. In some cases their reach is wide and deep, in others not. Peck (2006: 732) summarises well the research agenda that follows from this: "If neoliberalism can only exist in hybrid, in a kind of parasitic relation to the social formations that provide its hosts, then there is ... considerable work to do in mapping varieties and transmutations of the project". ${ }^{17}$ See Figure 1.

\section{Neoliberal environments: introducing the topic and the published research}

As already stated, critical social scientists interested in environmental management, natural resource use and related issues came late to the discourse of 'neoliberalism' when compared with most of those whose work I've cited above. Even so, they had been talking about at least some of the same phenomena by way of other terms - such as 'free market environmentalism' (e.g. Eckersley, 1993). Since roughly 2000, they have linked these terms to the concept of neoliberalism or else, for various reasons, bypassed the former and utilised the latter as an analytical framing device in their research.

\section{Neoliberal environmental policy: history and declared benefits}

Environmental and natural resource policies that deliver one or more elements of the seven-part neoliberal policy program have been implemented in a wide range of contexts and locations. The question arises: given that neoliberal ideas originally made little or no reference to natural resources or environmental issues, why did they find expression in water, forestry and fisheries management

\footnotetext{
${ }^{17} I t$ 's an agenda advocated by several others too (Larner, 2003; Larner 2000; Clarke, 2004; Castree, 2005; Kingfisher and Maskovsky, op. cit.; England and Ward, 2007; Leitner et. al., 2007). It amounts to tracking the temporal and geographical circulation, modification, hybridisation implementation, revision and (in some cases) abandonment of neoliberal ideas. At its most ambitious, it involves determining the reciprocal links between, and conjoint effects of, neoliberalism as worldview, program and policies in any given case. This would enable us to identify varieties of neoliberalism and to understand whether, how and why they have succeeded in their own less-than-homogenous normative terms. It would also oblige us to acknowledge the fact that, in some cases, the mere presence of elements of worldview, program or policies does not, in itself, entitle us to conclude that these are defining elements. They may, in fact, be less than hegemonic in certain situations since their presence in one or other policy domain does not make them definitive of an entire policy regime, let alone an entire social formation. As things stand, there is no consensus on how one identifies a 'variety' of neoliberalism (see section VI below) - though several economic sociologists and international relations scholars have scarcely hesitated here, as if the complex ontological, epistemological and methodological issues just highlighted were of little consequence. For now, I will also bracket these complexities as I move on - at long last - to discuss nature's neoliberalization.
} 
(to take just three examples) in many places, regions and countries? The published research literature suggests that there are five answers to this question, even though the complete history has yet to be detailed.

First, Steven Bernstein (2002) points to the entirely contingent coupling of environmentalism and neoliberalism during the 1980s - what David Driesen (2008) calls a 'shotgun wedding'. The global rise of environmental concern through the 1960s and 70s, Bernstein argues, coincided with the success of neoliberalism in the Anglo-American world and, via the World Bank, IMF and World Trade Organisation, at the global level through the 1990s (see also Hartwick and Peet, 2003). Yet post-war environmentalism's origins can, of course, be traced back to the Fordist-Keynesian, pre-neoliberal period, one which ended with widespread talk of an 'environmental crisis'. Second, environmentalism aside, the idea of 'green development' took hold in several global institutions from the late 1980s. The idea was that in the global South there were many 'unpriced' and often unowned biophysical 'assets' that could, if inserted into global markets, create revenue streams able to support much needed socio-economic development. These assets included everything from rare and beautiful animal species to plantation trees or mineral resources traded overseas. Third, in some (but by no means all) domains of environmental management and natural resource policy, neoliberal ideas had already been aired quite separately from the broad manifestos authored by the likes of Friedman and Hayek. For instance, during the 1950s economist H. Scott Gordon had suggested a proto-neoliberal solution to over-fishing in which private property and markets played a major role (Gordon, 1954), while the famous essays authored by Garrett Hardin $(1968,1974)$ a decade-plus later popularised similar ideas for all 'open access' resources. The term 'neoliberal' was not used by Gordon or Hardin, but their arguments were consistent with the neoliberal worldview. Fourth, because many natural resources (e.g. water and forests) had been managed by state bodies as public services or national assets post-1945, it was inevitable that neoliberal politicians - such as Margaret Thatcher - would seek to manage these resources using the same political-economic rationality utilised in all other areas of economic and social policy. Finally, in the USA a small group of think tanks and foundations worked very hard from the late 1970s to popularise 'green neoliberalism' (Goldman, 2005) as a way of responding to the concerns of the green movement yet without capitulating to 'command and control' solutions. This later had effects on American environmental policy arguments on the world stage. In short, there was no single reason why neoliberal ideas seeped into the arena of environmental policy. It was an uneven process temporally and spatially, and the three 'fields' identified by Mudge (op. cit.) were all involved in various ways and to varying degrees.

What's clear, with the benefit of hindsight, is that the growth of environmental and resource economics as an applied field of academic research was very important in codifying an environmental version of neoliberalism as - 
variously - a worldview, a policy program and a set of concrete policies. This sub-discipline's prodigious growth in universities (a key part of the 'academic field') from the early 1980s was a reflection of/response to the five developments recounted above, and - in turn - gave neoliberal ideas further impetus in the environmental domain. What is also clear in hindsight is that the international policy networks and epistemic communities that ensured neoliberal ideas 'travelled' in areas like social and labour market policy, were also effective in disseminating 'green neoliberalism' and 'green developmentalism' far and wide. The first United Nations 'Earth Summit' (1992) was a key event in this regard because the now famous Framework Convention on Climate Change and the Biodiversity Convention both embodied neoliberal principles, and they did so at a global level. Yet this is not to say that these principles infused environmental policy everywhere and equally. ${ }^{18}$

The neoliberalisation of environmental management and resource use necessarily occurs against the background of pre-existing political and moral economies. It must also grapple with the biophysical specificities and peculiarities of particular resources, ecosystems and environmental assets. In short, the world is never a tabula rasa waiting to be freshly inscribed by omniscient elites. Seen in this light, neoliberalisation must overcome, or at least adapt to, challenges and barriers residing in both the human and non-human domains. In any given case, neoliberal ideas, policies and practices must hybridise - more or less successfully - with what's already there.

The socio-economic and cultural obstacles to nature's neoliberalisation are, in theory at least, more tractable than are the biophysical ones. Though 'nature' - in the sense of the environment in general, and natural resources in particular - is undoubtedly a social construction at one level, it also possesses material properties that any governance regime or policy measure must work with (or around). ${ }^{19}$ By contrast, those stakeholders who stand to lose or gain from nature's neoliberalisation in any given case can, in principle, be persuaded about its merits or otherwise obliged to live with it. The various arguments made in favour of neoliberal environmental policies by their various supporters include the following:

\footnotetext{
${ }^{18}$ We should, before proceeding any further, make an important distinction of both real and analytical consequence (and which has only been implicit thus far in this essay). When considering the 'neoliberalization of nature' we can discuss one or both of the following, depending on how thoroughly we wish our examination to be. First, there are those neoliberal policies that are not ostensibly about environmental goods and services, but which have real biophysical impacts nonetheless (such as free trade policies). Then, secondly, there are those neoliberal policies that take environmental phenomena as the explicit object of attention (such as water resources policy). In what follows I will be surveying research that focuses on the latter for the most part, meaning that I am - in truth - missing a key section of literature on nature's neoliberalisation. However, to survey this other literature would, at the least, entail doubling the length (and complexity) of this already long essay. ${ }^{19}$ These properties are relative rather than absolute - but real nonetheless. They can, perhaps, be 'ignored' in the short term, but not in the medium- to long-term since inappropriate regulatory measures will - eventually - lead to visible and possibly harmful environmental problems.
} 
- open-access resources can be protected once private property rights and prices are assigned to them - 'commons tragedies' can thus be avoided;

- currently unowned or unpriced portions of the biophysical world can yield a profit for existing or aspiring entrepreneurs - either through conservation/protection/remediation or productive use;

- environmental goods that are not currently valued economically or else subsidised by the state equate - to 'lost income', 'unrealised value', or 'mis' / 'under-priced' assets for nature and people;

- the private sector can manage natural resources/environmental services so as to deliver 'value for money' for consumers or citizens relative to state bodies and other non-market actors;

- introducing competition and pricing into the management of the biophysical world can drive-up management standards and environmental outcomes;

- introducing commercial principles into state bodies can make them more efficient managers and deliverers of resources and environmental amenities or services;

- off-loading some state responsibility for the quantity and quality of environmental goods and services to civil society actors is both empowering for them and permits tailored, creative, nonbureaucratic approaches to resource governance;

- empowering consumers, citizens, firms and other juridical units to take responsibility for their environmental impact respects the rights of the 'individual' (real, communal or corporate).

We might synthesise these various arguments, as follows. Depending on the case, neoliberal environmental policy can - so advocates claim - deliver benefits summarised in the acronym GEDDS. This stands for economic growth (through privatising and marketising biophysical resources, goods and services); economic efficiency (the best environmental outcome per unit cost, where outcomes are described in various management standards and codes); economic and social development for marginal or low income communities (as new revenue streams kick-in underpinned by secure property rights in land and other resources); democracy (by de-statising responsibility for, and the benefits of, environmental management); and environmental sustainability (by making conservation, preservation, restoration and renewable use profitable activities). I realise entirely that this is something of a contrivance on my part because I am grouping arguments made by different advocates operating in different fields of environmental thinking and policy. In any given case, not all five criteria would be relevant. However, to the extent that these arguments are advanced selectively to support the policies analysed by the critics whose work I turn to in 
the next main section, I think GEDDS is a useful heuristic when seeking to map these various policies' diverse effects (see section V below).

\section{Researching neoliberal environmental policy}

Most analysts of 'neoliberal nature' are not so sanguine about the purported benefits of market-led environmental governance. The first purposeful and collective use of the idea of neoliberalism to investigate environmental questions occurred in 2004 and 2005, when the journals Geoforum and Capitalism, Nature, Socialism both devoted whole issues to the subject. This led to the edited book Neoliberal environments (Heynen et al., 2007), inspired special issues of the journals Antipode (Mansfield, 2007) and Conservation and Society (Igoe and Brockington, 2007), inspired a special section of Geoforum (Guthman, 2008a), and triggered a steady stream of empirical studies in several disciplines that use 'neoliberalism' as a framing concept or analytical lens. These studies focus on the full spectrum of environment and natural resource uses, from 'extraction' (e.g. mining or agriculture) to conservation, and from 'green' policies to those in which nature is simply something to be exploited for profit. 'Neoliberal environmental policies' are neither intrinsically 'anti-ecological' nor always hard-wired to the 'sustainability' agenda: it very much depends.

As I said earlier, the signature feature of this recent literature is its commitment to case study research (though some of it is synoptic and general see, for instance, Guthman [2007], Roberts [2008] and Buscher et al. [2011]. For the most part, it comprises in-depth analyses of neoliberal environmental policies in specific places, regions or countries. It is thus, to recall Peck and Tickell's term, interested in various neoliberalisations. What is more, and broadly speaking, it takes a political economic perspective on neoliberalization rather than a Foucauldian one (Higgins \& Lockie [2002], Sullivan [2006] and Fletcher [2011] being among the relatively few exceptions). ${ }^{20}$ The latter, sometimes called a 'governmentality' approach to neoliberalisation, has inquired into the 'technologies of government' or the 'rationalities of rule' - not just administrative ones, but also those rhetorical and discursive technologies generative of new subject-positions and identities in the wider society. The key point has been that neoliberalism - despite its principles - has involved more (or as much) government not less, especially outside the formal apparatuses of the state. It is 'rule at a distance' or by 'remote control' because of the way it reformats social norms so as to create - rather than simply 'activate' the supposedly latent and intrinsic - capacities of 'individuals' (be they real or corporate). ${ }^{21}$

\footnotetext{
${ }^{20}$ Some see the two approaches to neoliberalism as complimentary: see Lockwood and Davidson (2009), for example.

${ }^{21}$ I suspect this Foucault-inspired research into neoliberalism and environmental governance will grow in importance, not least because Foucault's lectures on 'biopolitics' were recently translated into English.
} 
Inspired by (neo)Marxist, Polanyian and Gramscian ideas, where some political economic perspectives differ from Foucauldians is in seeing neoliberal statecraft as, variously, (i) a project of class domination hidden behind, or expressed in terms of, the rhetorical worldview; (ii) generative of new social inequalities and injustices, or the intensification of existing ones; and (iii) a farfrom-smooth process that's often generative of social resistance framed in class, community, gender or other terms (which power-elites, within or without the state, then have to manage in some way - what Polanyi termed 'the double movement'). I might add that some of this Marxian-Polanyian-Gramscian work has analysed neoliberalism in light of recent theoretical work on capitalismecology relations in general - work by 'ecoMarxists' such as James O'Connor. A motif of these ecoMarxists, unsurprisingly, is contradiction: not just the classic 'first' contradiction internal to capitalism, as identified by Marx (between the 'forces' and 'relations' of production), but also the 'second' contradiction between a growth-orientated capitalism and the finite biophysical world upon which that growth depends. In this light, three questions arise: first, does the 'neoliberalization of nature' constitute a widening or deepening of class-based social power? ${ }^{22}$; second, does neoliberalism simply perpetuate, mitigate or even 'overcome' the 'ecological contradictions' characteristic of capitalism to-date? ${ }^{23}$; third, how successfully have neoliberals managed to frame their policies discursively so as to get 'buy in' by various affected constituencies? When combined, the answers to these questions speak to the organic relationship between issues of social justice and environmental justice.

These theoretical-political commonalities in the research literature notwithstanding, the empirical inquiries are far from easy to parse and synthesise so that a broader understanding of 'neoliberal nature' can be achieved. Why so? First, the published studies are now relatively numerous and scattered across a wide range of journals in a variety of academic fields (including human geography, rural studies, planning, anthropology and agrarian studies). Second, these studies together span a wide range of environmental policy areas (e.g. water resources, forestry, mining and fisheries). Third, while some studies are local-scale, others examine national or international policy measures. Fourthly, the geographical cases selected are highly diverse, and span the developing and developed worlds. Finally, different aspects of neoliberalization have been focussed on in specific studies. For instance, geographer Julie Guthman's excellent research on voluntary food labels combines a focus on one specific policy instrument (devised in the 'policy field') with a wider discussion of how 'neoliberal consumers' are made (an aim of the neoliberal worldview writ-large). This links back to my discussion in section II: the scope of what 'neoliberalism is (or is understood to be) is such that few studies could consider all its elements in one go. For these five reasons, a major

\footnotetext{
${ }^{22}$ This question has frequently arisen in respect to enclosures of environmental 'commons'.

${ }^{23}$ The theoretical literature authored by ecoMarxists such as James O'Connor, Ted Benton, Elmar Altvater and John Bellamy Foster is undecided on this question.
} 
effort is required on the part of readers of this literature to detect the proverbial signals in the noise. The empirical studies into neoliberal nature have emerged bit-by-bit, and in many cases are not cross-referenced by their authors to all the relevant published literature. Additionally, these studies have increased greatly in number in a short space of time (e.g. in the last year several publications by Bram Buscher have appeared in a range of journals - see Buscher 2010a, 2010b, and Buscher et al. 2011).

In what follows, I will attempt to locate the findings of the separate studies on a broader cognitive map without, I hope, imposing a false sense of order or unity on them. The value of this exercise is, I trust, obvious: if 'neoliberalism' is as widespread and influential as its critics have claimed, we need to examine it holistically and comprehensively - rather than fixate on one or a few cases and examples as if they can tell us the whole story. Yet because the published studies have proceeded according to no common template or method, it is timely to create a greater sense of analytical order when deciphering their potentially disparate results and insights. Inevitably, some of the empirical (and conceptual) richness of the research I describe will be sacrificed in the process of presenting my synopsis. ${ }^{24}$

\section{Neoliberalizing nature 1: processes of re-regulation}

I summarised the purported benefits of neoliberal environment policies with reference to the acronym GEDDS. In toto, the arguments made by advocates here can be said to constitute the neoliberal worldview in the environmental domain. In what real life situations have they been translated into practice? I'll address this question systematically, according to the seven-point description of the neoliberal policy program presented earlier. Note that no one author's study speaks to all these points, yet when taken together different studies do speak to these points as a whole. I will then, in the next section, describe the outcomes of nature's neoliberalisation, organising these according to social and environmental impacts and then the GEDDS template. This, it seems to me, is far more incisive than discussing policy change on a sector-by-sector basis (e.g. agriculture, forestry, fisheries etc.). It also allows us to see how sector-specific reforms are part of a broader transformation of economy, society and environment. Together, specific neoliberalisations of environmental and natural resource use amount to the 'neoliberalisation of nature' as a whole.

\section{Privatising and propertising nature}

Assigning rights of ownership in, or use of, the biophysical world can occur in three situations: namely, where state bodies relinquish or 'loan' their sovereign rights, where a recognised/established rights regime outside the state realm is

${ }^{24} \mathrm{I}$ hope, therefore, that this essay is merely a way-station that will lead many readers on to a close study of the studies referenced in the extensive bibliography. 
fundamentally altered by policy makers, or where no recognised (or enforceable) rights currently exist.

Karen Bakker $(2003,2005)$ and Loftus \& Macdonald (2001) provide examples of the former. Bakker's detailed studies of water and sewerage services in post-1989 England and Wales show how a few large private sector firms took direct control of these countries' hydrological infrastructure. Similarly, Loftus and Macdonald describe President Carlos Menem's 1989 National Administrative Reform Law and focus on the privatisation of water delivery and sewerage services in Buenos Aires through the 1990s. This concentrated water management rights in the hands of one large company, Aguas Argentinas. Studies of the second situation identified above include those by Thomas Perreault (2005, 2006), Diana Davis (2006), Gavin Bridge (2002) and Becky Mansfield (2004a, 2004b, 2007b). Perreault (2005) focuses on the legal enclosure of Bolivia's water resources in the 1990s and gas resources too (Perreault, 2006). In the former case, central state control of the resource was relatively weak prior to privatisation. Davis describes the several laws passed in Morocco in the 1990s pertaining to unfenced, rural farmland and to dryland agriculture. These laws have involved enclosing the environmental commons, creating large parcels of agricultural land, and concentrating ownership in a new set of well capitalised farmer-operators.

Focussing on Guyana, Gavin Bridge (2002) charts the enclosure of land by both small and medium domestic investors, and large overseas investors, together purchasing prospecting and extraction gold mining rights from the national state. After the 1989 liberalization of mining laws, this poor and indebted country saw a fifteen fold increase in the area given over to mining permits or claims by 1994. Gold mining in the country has historically been dominated by small and medium domestic operators. An early 90 s amendment to national mining legislation was designed to encourage large overseas investors to enter the Guyanese gold industry. But the amendment was also designed so that overseas interests had to have domestic partners, a way of trying to make external investment pay dividends for certain Guyanese nationals. In contrast to Bridge's land-based study, Mansfield's (2004a, 2004b, 2007b) excellent essays focus on the enclosure of the US portion of a previously open access fishery in the North Pacific Ocean during the 1990s (see also St. Martin's [2007] study of recent New England fisheries and Ibarra et al. [2000] on Chilean, Mexican and Peruvian fisheries management). This enclosure has excluded new fishery entrants and, indeed, reduced the number of existing ones.

In respect of the third situation identified above, geographer Scott Prudham (2007) analyses a 2004 Canadian Supreme Court decision to reject a Monsanto patent claim covering genetically modified canola. Prudham focuses on the legal complications attendant on trying to abstract discursively parts of nature from their social and environmental integument in order to present them as putatively 'autonomous inventions' by the likes of Monsanto. This case is linked to ongoing attempts by many other pharmaceutical, biotech and agro-foods 
companies to privatize previously unowned (and unownable) elements of the biophysical world. Relatedly, there are Morgan Robertson's (2004, 2006, 2007) fascinating studies of the wetland banking and water quality credit markets in the US during the 1990s and the noughties. His essays examine how the right to destroy and create wetlands was invented and institutionalised, so too the right to produce dirty and clean water. In both cases the rights were new, creating a property regime where one did not really exist before. The same applies to the Californian conservation easements investigated by Amy Morris (2008).

\section{Marketizing biophysical resources, goods and services}

Rights of ownership or use of nature do not necessitate the marketization of biophysical resources, services or assets (Bakker, 2005). However, for neoliberal policy makers the two are umbilically connected. Once property rights are assigned and legally 'real', the assets owned or accessed should, neoliberals argue, generate a stream of revenue. Therefore, each of the studies cited in the previous three paragraphs necessarily includes mention of marketisation. For instance, Mansfield's research explores how a transferable quota system was introduced which allowed fishermen and other stakeholders (e.g. coastal indigenous peoples in Alaska) to establish a price for the annual right to harvest a given amount of fish. Additional studies in which marketisation is a central theme include the following. Fraser Sugden (2009) reports on the Nepal government's Agricultural Perspective Plan (1996-). This plan aimed to get subsistence farmers in rural areas to commercialise their operations so as to earn exchange values from food sales to domestic and overseas markets. In other words, the plan sought to replace a long-standing peasant way of life with a capitalist one comprised of numerous agrarian entrepreneurs vying for market share. Likewise, Cristobal Kay's (2002) superb analysis of Chile's neoliberal agrarian transformation includes a discussion of 1990 s attempts to bring peasant farmers into the country's capitalist economy by trading their produce overseas or domestically. This 'second modernization' of Chilean agriculture is also the focus of Warwick Murray's (2002) wide-ranging study of rural reconversion.

A striking case of marketization is presented by James McCarthy (2004), in his analysis of how large firms within the NAFTA region use the investor protections written into this Agreement. Where Robertson and Morris (see previous subsection) both show marketization to be an attempt to mitigate environmental harm, McCarthy tells a different story. In 1993 a US wastedisposal company Metaclad bought, and subsequently developed, an inactive toxic waste dump in the Mexican state of San Luis Potosi. The local government halted Metaclad's activities in 1995 on health and safety grounds. Metaclad subsequently began a proceeding against the Mexican government under Chapter 11 of NAFTA, citing the 'regulatory takings' concept which presumes that investors are entitled to earnings lost through the actions of others. In 2000 a NAFTA tribunal found in favour of Metaclad, ordering Mexico to pay $\$ 16.7$ million for outlays and lost revenue. McCarthy calls this the 'primitive 
accumulation of the conditions of production', because revenues are extracted from the biophysical world not through productive activities but, rather, by seeking compensation for not undertaking such activities. The right of firms to make money regardless of the human or environmental cost is taken as sacrosanct here, in McCarthy's view.

\section{State roll back or deregulation}

Clearly, the withdrawal of state control of (or involvement in) environmental goods, ecological services and natural resources has not been universal over the last 30 years. In many countries such control and involvement has been minimal from the get-go (think of many developing countries), while in others it has been considerable (notably Western capitalist democracies, former communist states, and former 'developmental states' in the global South). Only in these latter cases is 'roll back' a significant and tangible process, often driven by a perceived need of state bodies to save money and reduce public borrowing or taxation. For instance, Harold Perkins (2009) reports on a sharp reduction in local government expenditure on local environmental amenities in the famously 'green city' of Milwaukee through the 90s and noughties (see also Heynen and Perkins, 2005). Also in the USA, Robbins and Luginbuhl (2005) show that in California, Colorado, Nevada, New Mexico, Oklahoma, Oregon, Utah and Washington there has been a transfer of fiscal and management responsibility for wild game from states to (mostly) private landowners, such as farmers according to their land acreage and the habitats involved. As already mentioned, Bakker $(2003,2005)$ relates how central government off-loaded responsibility for water supply and sewerage infrastructure in England and Wales post-89. Also in the Anglophone world, Brad Coombes (2003) reports on New Zealand's 1991 Resource Management Act and its effects on habitat husbandry in the Auckland region. After the Act was passed, central government devolved many of its strategic planning powers, in the process weakening the influence of professional planners on land use decision making. In turn, this left the protection of rare or otherwise valuable habitats on privately owned land parcels to a combination of voluntary agreements and market-based instruments. More dramatically, Prudham's (2004) study of a serious water poisoning incident in Walkerton, Ontario, describes the context as being a contracting out of provincial government responsibility for water testing as part of premier Mike Harris's 'common sense' agenda in the 1990s.

Western capitalist democracies aside, Maria Rodriguez (2003) recounts how one of Brazil's post-1945 parastatals - Companhia Vale do Rio Doce (a conglomerate of 50 firms operating in the mining, transportation and forestry sectors) - was sold-off to private investors in 1997. This involved a massive withdrawal of national state authority, though it generated an equally massive infusion of funds into the public purse. Also in South America, Jessica Budds (2004) focuses on the Pinochet government's reversal of previous government 
policy on water rights and water delivery so that the hydrosocial cycle was destatised.

\section{Market-friendly reregulation}

The processes of privatisation, marketisation and deregulation do not, of course, mean that national governments somehow play a minor role in neoliberalisation. On the contrary, their active involvement is imperative, both as law makers and as direct (or indirect) regulators of actors inhabiting the private and civil society domains. This involvement can redefine market relations across the board and affect all market participants, not least by making new markets altogether (or significantly altering existing ones). Typically, the regulatory environment has shifted from formal, state-centred government to more dispersed, extra-state forms of governance.

Studies of market friendly reregulation by national governments abound. Once again I need to mention Bakker (2003), whose book An uncooperative commodity details the extraordinary lengths technocrats operating under elected Conservative governments went to make a market in water supply. Cocklin et al. (2006) and Pritchard (2005a, 2005b) relate how post-80s Australian governments lent their full support to free trade policies in the agricultural arena, creating a 'hyper competitive' farming sector oriented to global export markets. This contrasts with the EU, which used the idea of 'multifunctionality' to protect certain of its farmers and rural communities from the negative effects of laissez faire (see Dibden et al., 2009). Relatedly, Clive Potter (2006) reports on how a globally powerful discourse of free trade in the agricultural sector has heavily conditioned national attempts to exempt some rural spaces from competitive, productivist agriculture - casting a long 'discursive shadow'.

Budds' (2004) already cited study of Chile's 1981 Water Code shows how it created an expanded market in water rights, and thus water itself. Focussing on nearby Peru, Jeffrey Bury $(2004,2005)$ explains how successive governments opened-up their country's mineral resources to overseas investors through the 1990s (echoing Bridge's study). Levine (2007) describes how Zanzibar's 'Environmental Management and Sustainable Development Act' devolved responsibility for protected areas to private parties. These parties can include local communities, as detailed by Igoe and Croucher (2007) for Tanzania, and by McCarthy (2006) for British Columbia. In her account of Madagascar's turn to ecotourism as a major source of overseas income and way of protecting special or biodiverse sites, Rosaleen Duffy (2008) places emphasis on the wide array of actors who have been invited to neoliberalise access to the island's flora and fauna. These actors cross-cut geographical scales and the public, private and third sectors - together they show how a national government has been influenced by, or actively enrolled, quasi-state institutions (like the World Bank), well-funded environmental NGOs and many others besides. This theme of the state-sanctioned turn away from government to governance is emphasised by Tom Perreault $(2005,2006)$, in his already mentioned account of the 
privatisation of rights to gas and water resources in 1990s Bolivia. This privatisation entailed a radically altered access regime and a newly centralised regulatory system dominated by national quangos staffed with bureaucrats and technicians. Relatedly, Buscher and Dressler (2007) show that national states in the global South have, since the early 90s, designated more cross-border areas in order to encourage privately (or communally) managed conservation spaces to emerge.

Prudham and Morris (2006) also look at a quango, but in Canada. They scrutinize a national review of GM (genetically-modified) foods regulation by the Canadian Biotechnology Advisory Committee (CBAC) between 1999-04. GM foods have, of course, been heavily criticized on environmental and health grounds by the likes of Greenpeace and Britain's Soil Association. Prudham and Morris show that, from the start, the CBAC - a supposedly impartial expert body advising the Canadian government - was already committed to creating a market for GM foods and spent a good deal of its energy trying, subtly, to persuade the Canadian public that this was a good thing. Finally, there's Julie Guthman's (2007) study of voluntary food labelling schemes which connect farmers and shoppers. These schemes, she argues, create an ethical market in socio-environmental 'goods' and 'bads' in place of direct national state regulation of farming and food prices. They thus put a monetary value on morality in competitive markets, thus making exchange values a vehicle for expressing consumer's environmental and social values.

\section{Use of market proxies in the residual state sector}

In relation to the non-human world or society, the use of market proxies entails making remaining state-run activities as economically efficient as is possible. 'Efficiency' here means that, whether delivering goods and services to citizens or acting as a regulator, state institutions operate as if they were private sector firms subject to a competitive environment. Where 'artificial' competition cannot be created among state institutions for practical reasons, other measures can be used, like rules insisting on full cost-recovery, balanced budgets and high standards of service provision.

In the biophysical domain, one service area where even many neoliberal states find it difficult to 'let go' relates to 'basic' natural resources like water and oil - resources that are either universally required by all citizens or which have strategic importance for a given country. Laila Smith's (2004) study of water provision in Cape Town in a case-in-point. In an empirically rich essay, Smith shows how the Cape Town government introduced water-demand management (through metering and pricing), the outsourcing of some water services as a cost recovery strategy, and water cut-offs for non-paying citizens. This, she shows, was done in the name of 'economic efficiency' and a market-defined notion of citizens' deserts. Relatedly, Priya Sangameswaran's (2008) study of water resource governance in the Indian state of Maharashtra suggests that an attempt to commercialise a parastatal service provider - Maharashtra Jeevan Pradhikaran 
(MJP) - are radically altering its modus operandi. However, aside from Smith's and Sangameswaran's studies there are currently few others that interrogate nature's neoliberalisation in the residual state sector.

\section{The strong encouragement of 'flanking mechanisms' in civil society}

The 'gaps' left in environmental provision by state bodies can be plugged by various civil society actors. These plugs can occur outside or within the market, depending. The Milwaukee research conducted by Perkins (2009) provides an example of the former, as does Ryan Holifield's study (2004). Perkins recounts how three volunteer organisations stepped into the vacuum created by the Milwaukee municipal government's partial withdrawal from maintenance of public parks and trees. Holifield examines how so-called 'environmental injustice communities' (EICs) were, during the Clinton Presidency, brought into the regulatory practices of America's Environmental Protection Agency (EPA). In neoliberal terms, EICs are those communities suffering the ecological 'externalities' of economic activity: they are victims of 'market failure' (such as toxic waste being dumped nearby without the EJC in question gaining financial compensation or the offending firm/s having to pay the clean-up costs). Holifield shows how, under Clinton, EICs - whose politics over the last 30 years have typically been radical-left, linked as they are with the civil rights movement of the 1960s - were given much more visibility within the EPA's remit to remediate toxic sites. Though EICs are not, Holifield argues, products of neoliberalism, they have been brought within its logics of property and payment by the EPA. This contrasts with a previous situation where EICs were typically ignored by state officials unless they fought hard and loud enough to get their grievances heard. In a recent study of agricultural biosafety in Costa Rica, Thomas Pearson (2009) recounts the appearance of 'informal auditors' in civil society, who check the work of state-sanctioned private auditors. In contrast to Holifield's study, Pearson shows that these auditors were not, in fact, brought forth intentionally through state encouragement. They arose spontaneously because of a lack of trust in the private sector auditors.

As I intimated above when discussing Guthman's (2007) research into voluntary food labels, civil society actors have been increasingly enjoined to take-on a regulatory role outside the state apparatus through the moralisation of certain commodity markets. Paige West (2010) and Heather Lovell et al. (2009) examine similar cases where commodity exchange becomes a substitute for state management of environmental and labour conditions. West looks at how Papua New Guinean speciality coffee is marketed to US consumers, whose dollars purport to deliver decent wages and decent environmental conditions on the other side of the world. She shows how marketing's subject-effects - to the extent they exist - individualise consumers and systematically misrepresent coffee producer's lives in neo-colonial, romanticised narratives of peasants and family farmers. Meanwhile, Lovell et al. describe the equally contrived ethical 
narratives-cum-discourses thrown at purchasers of voluntary carbon offsets by offset retailers.

Consumers are, of course, positioned at the end of 'commodity-chains'. But these commodities are often produced, and marketed, according to standards that are prescribed by non-state actors and adhered to voluntarily by certain firms and commercial outfits. Dan Klooster (2010) details the globally widespread adoption of Forest Stewardship Council (FSC) certification standards for wood product emanating from plantation forests. These voluntary schemes have the value - so argue their advocates - of creating global standards without the need for complicated, cross-jurisdictional administration by national regulators.

\section{The creation of 'free', 'self-sufficient', self-governing and entrepreneurial individuals and communities}

Most markets involve a wide array of actors, often separated in space and time (the relations between which commodity chain analysts scrutinise). Because all markets are 'embedded', their operation affects diverse other constituencies. We can thus imagine neoliberal discourse having to work in several different arenas so as to suitably 'interpellate' commodity producers, sales and marketing intermediaries, commodity consumers, regulatory actors or other stakeholders affected by nature's neoliberalisation. These various actors may inhabit the same national space; but, then again, they may not.

The already mentioned studies by Sugden (2009), Murray (2002), Kay (2002), and St. Martin (2007) focus squarely on those deriving a livelihood directly from utilising natural resources (e.g. land or fish). Sudgen points to the failure of neoliberal agrarian reform in the Nepali lowlands - existing social identities and relations have not been dislodged discursively or practically. By contrast, though he does not examine identities and subject-positions, Murray's research into agrarian transformation under Chile's Concertacion governments demonstrates how small, medium and larger farmers embraced neoliberal policy - though not always willingly. This, too, is the message of Kay in a similar study of Chilean agriculture. St. Martin examines how a neoliberal fisheries discourse promoted by policy makers articulates with a non-capitalist political and moral economy specific to New England fisheries. It does not, in his view, erase this existing economy, but it does threaten to unsettle it considerably even as fishermen seek to maintain their traditions (see also St. Martin, 2006)

Other commodity producer focussed research worthy of mention here is that by Peter Wilshusen, Wendy Wolford, Becky Mansfield and Gabriela Valdivia. Wilshusen's (2010) field research in southeastern Mexico (Quintana Roo) relates how rural communities have creatively worked with, and around, neoliberal discourses and policies emanating from the national state. These communities, he shows, have accommodated neoliberalisation by blending its favoured subject-positions and rationalities with those of a moral economy based on collectivist ideas of sharing and mutual aid. Wolford's (2007) 
investigations of land reform in northeastern Brazil demonstrate how neoliberal discourse has been utilised enthusiastically by members of the populist Movimento dos Trabalhadores Sem Terra. However, the price for their support, she argues, is that many now feel obliged to participate in a competitive, exchange-value based food economy rather than a peasant one. In an essay on Alaskan indigenous peoples' involvement in a transferable quota fisheries scheme, Mansfield (2007b) reports a similar enthusiasm for neoliberalism among an otherwise excluded social group. The rights and revenues enjoyed by First Nations Alaskans, she shows, are consistent with their sense of themselves as distinct community with historical and cultural claims to a share of the fishery, and in need of monies to address poverty and to underpin socio-economic development. Relatedly, Valdivia (2004) examines the way neoliberal reform measures in the Ecuadorian Amazon have affected indigenous people's discourse in respect of land and other resources. She reports a creative, complex engagement with neoliberal principles and ideas, allowing indigenous peoples to adapt their claims and agendas to changing political economic circumstances. Of course, in many cases of nature's neoliberalisation there is little or no need to 'cultivate' suitable producer identities - notably, in those cases where large private corporations are invited to invest in land, water, forests, fisheries and the like in order to make money.

Perreault's $(2005,2006)$ studies of Bolivia's gas and water wars cross-cut people's identities as citizens and commodity consumers. Though the reasons are very different to those recounted in Sugden's Nepal study, he shows how neoliberal rhetoric failed to prevent serious public protests over the reform of water and sewerage services, and the management of natural gas reserves. By contrast, and as earlier mentioned, in her more consumer-oriented study, West (2010) suggests that neoliberal subjectivity 'works' for speciality coffee sellers in the US but not because consumers really understand (or even care about) the ethical issues or the salient facts. Guthman (2008b), meanwhile, maintains that voluntary labelling schemes for organic food have taken-hold among food activists and many left-wing consumers because they genuinely appear to deliver some sort of socio-ecological justice at the production end of the commodity chain. As she explains elsewhere (Guthman, 2008c), this appearance is, in part, made possible by the active interpellation of individuals into the policy norms and moral goals of neoliberal discourse - these norms and goals are, as it were, the only 'realistic' ones on offer.

\section{Neoliberalizing nature 2: social and environmental effects}

In the previous section I focussed on the multifaceted process of neoliberalizing human engagements with the non-human world. Depending on the study cited, more than one facet of the process has been the focus of analytical attention. Though the precise details vary, I've described these facets under one or more of the seven headings that pertain to neoliberalism as a policy programme. This reveals the sheer breadth of projects to neoliberalise environmental use and 
resource management. These projects range from the reform of ownership rights to how new forms of subjectivity are engendered among resource users. So far so good. But what have been the effects of nature's neoliberalisation in various times and places, according to the published research we have so far? In posing this question, the answer to which I've only hinted at in the previous section, I am well aware that separating 'process' from 'outcome' is artificial, ontologically-speaking, since arguably the latter is part of the former (not some sort of stable end-point). Even so, the distinction has a heuristic value in that it describes the (albeit eventually changeable) outcomes of process at a given moment in time. Indeed, several published studies have focussed specifically on these outcomes, as we'll see below. I will further distinguish between the social and environmental effects of policy measures (though, again, in reality they are intertwined). Needless to say, in the detail the precise socio-environmental effects of neoliberal policies vary according to their particular type and the spatio-temporal scale we are interested in. It almost goes without saying too that all effects are relative - relative to who (or what) is affected, in what way, and to what degree. ${ }^{25}$

Rather than summarise the findings of all the relevant studies, I will mention some indicative ones and simply tabulate the many others that I could mention if I had more space (see Table 1). Several contributions highlight problems of ordinary people's exclusion from, or reduced access to, environments and resources upon which their livelihoods or well-being depends. For instance, consider Davis's (2006) already mentioned research in Morocco and Sugden's research in Nepal. Davis shows how peasant pastoralists were alienated from grazing territory in the name of large-scale, irrigated dryland farming by private landholders. Sugden, meanwhile, shows that agricultural reform has done little to release the very poorest farmers from disadvantageous feudal and rentier relationships. Budd's (2004) research in Chile reveals large scale farmers gaining greater access to rural water than do peasant cultivators, subsequent to neoliberal water reform. In her Virgin Islands study of conservation policy, Crystal Fortwangler (2007) points to the increased real estate prices outside the conservation zone, making land ownership more difficult for local people. Lisa Grandia (2007) reports on the exclusion of Guatemalan peasants from land given over to new commercial tree farms. Meanwhile, Igoe and Croucher (2007) make a similar observation about rural Tanzanians adjacent to a new wildlife management zone. Finally - to take one more example - Laila Smith's (2004) Cape Town research shows the socially regressive effects of water pricing under a new cost-recovery regime in the late 1990s. Economic equity has, she shows, been prioritised over social equity.

\footnotetext{
${ }^{25}$ This invites complex and differentiated judgements about how 'effects' are to be registered and evaluated. It would be facile to suppose that all the effects of nature's neoliberalisation registered in the published research can somehow be 'totted up' into some sort of aggregate 'score-card', even though my Table 2 gives the impression that this is a permissible practice. For more on this see Castree (2008b, section 4).
} 
By contrast, a minority of other studies are more equivocal than those just mentioned. For instance, there is Jeffrey Bury's $(2004,2005)$ detailed examination of how several rural households in the Cajamarca region of Peru have been affected by overseas mining investment. He concludes that many families have enjoyed increased access to both 'produced' and 'human capital', while several have suffered a decline in access to both 'natural' and 'social capital'. Somewhat differently, Perkins' (2009) analysis of third sector involvement in the maintenance of Milwaukee's green spaces shows that such involvement has proven personally empowering for many citizens.

Of course, the implementation of neoliberal policy in the environmental domain has resulted in several spectacular, well publicised reactions within civil society. Andrew Nickson and Claudia Vargas (2002) report on the failure of Cochabamaba water concession in Bolivia - the private company Aguas del Tunari has its contract cancelled after just 6 months in 2000. The background to the cancellation was national protests about low rates of economic growth and about persistent poverty and low or stagnant wages among large sections of the population. The sharp increase in water tariffs in 2000 allied to a loss of water use rights by many stakeholders led to serious protest. Such large scale dissent was repeated following the privatisation of gas resources in 2003 (Perreault, 2006). Less dramatically, Jill Harrison (2008) reports that neoliberalised agriculture in California has led to increase pesticide drift, eliciting vocal forms agro-food activism in civil society. Yet in other cases - despite manifest problems - neoliberal environmental policy has persisted. This is (or was) true for water governance in Buenos Aires. Loftus and McDonald (2001) show that even though consumer prices increased, many workers were laid-off in the water sector, and there was slow growth in new sewerage connections and treatment, the citizenry tolerated the policy shift (grudgingly or otherwise).

On the environmental side, neoliberal environmental policy seems to have had mixed effects. There was the shocking water poisoning case in Walkerton, Ontario, related by Prudham (2004). Equally alarming were two American firms' attempts to seek monetary compensation from state bodies for not polluting the commons in Mexico and California (see McCarthy, 2004). Less dramatically, Paul Robbins and April Luginbuhl (2005) examine recent attempts to create 'game farms' in California, Colorado, Nevada, New Mexico, Oklahoma, Oregon, Utah and Washington State. These initiatives, they show, not only go against a long history in the US that wildlife is just that - 'wild'; they additionally represent attempts to make wildlife pay for the benefit of a select group of ranchers and hunters. Robbins and Luginbuhl find little evidence that private wildlife managers are delivering effective animal and habitat husbandry as compared to a previous generation of state-officials.

Brad Coombes (2003) study of bush-lot subdivision in New Zealand, as a new way to protect indigenous habitats on private land, suggests that this approach is too ad hoc and proscribes any strategic intervention to ensure proper levels of ecological protection. Heynen and Perkins (2005) show the 
local government divestment from the maintenance of urban tree cover has led to a notable loss of ecological services (e.g. provision of shade) and that private landholders cannot, left to their own devices, compensate adequately for the reduction in tree numbers. A more mixed picture is painted by Maria Rodriguez (2003). Recently privatised iron ore and manganese operations in the Brazilian Amazon, she shows, are much more effective at protecting the local environment than their state-run predecessor. But, she argues, they remain ineffective at tracking environmental externalities outside the areas immediately adjacent to the mines. Bakker (2003) is more positive about the environmental effects of neoliberal reform. Her study of water privatisation in England and Wales shows both a reduction in leakage rates (due to huge investment in infrastructural renewal) and a notable increase in the quality of drinking water.

Bakker, like Jeffrey Bury, is among the few analysts who has sought to record both social and environmental effects of neoliberal reform in some detail. Though she acknowledges the environmental benefits of the shift away from direct state management of water resources in England and Wales, she also evidences new social inequities in water service delivery evident in the early 1990s. Specifically, lower income households were subject to water cut-offs on a scale previously unmatched, leading to a response by concerned regulators (Bakker, 2000).

What do these social and environmental effects tell us about nature's neoliberalisation when mapped against the criteria of GEDDS? What is clear, is that certain kinds of 'growth', 'efficiency', 'development', 'democracy' and 'sustainability' have been delivered by market-led environmental policies. However, the key - and obvious - point is that each of these terms has a contested meaning. The lack of universal or agreed definitions mean that analysts of nature's neoliberalisation, and the many people directly affected by it on the ground, have good reason to question the 'success' of the project. In various situations economic growth has disproportionately benefited private sector actors; economic efficiency has been achieved at the expense of social equity and justice; a very particular kind of 'development' has been achieved that does not reflect the full range of development thinking; democracy has been neutered; and sustainability achieved, but only to the extent that its consistent with the peculiarities of private property rights and market pricing.

\section{Key themes and conclusions}

Important as it is to pay close attention to the insights afforded by each of the empirical studies cited in the last two sections, it would also be easy to get bogged down in the detail. What, then, are the principal 'take home' lessons from the literature reviewed above, quite aside from the suggestion that the realisation of GEDDS is open to question? In my view there are six lessons, and I have identified them on the basis that they are evident in several separately conducted studies (though by no means all). In each case I present an illustrative example or two. As we'll see, many of the lessons apply to neoliberal state-craft 
more generally, regardless of whether or not we are discussing environmental management, regulation or governance.

\section{Making markets in environmental goods, services and assets typically requires considerable state intervention}

One of the shibboleths of the neoliberal worldview is that a reduction of state intervention in economy and society is both desirable and possible. Yet, as Karl Polanyi realised over 60 years ago, "Laissez faire ... [is] planned, planning ... [is] not" (1944: 141). In one of her several investigations of open access fisheries privatization, Becky Mansfield (2004a) makes the same point in compelling detail. She examines the implementation of the 1998 American Fisheries Act (AFA) as it affected the Alaska pollock population - the world's largest singlespecies fishery, and of major economic and social importance to Alaskans. The AFA led to sweeping change in the organization of this 'open-access' fishery, introducing a catch-quota system among a restricted group of relevant parties in order to prevent over-harvesting on environmental and economic grounds. Mansfield shows the remarkable degree of state regulation required to make the pollock fishery privatized and marketized. The AFA had to be interpreted and enforced by the North Pacific Fishery Management Council, which involved exceedingly detailed and complex regulations being developed to: (i) negotiate fair relations between inshore fisherman, offshore fisherman, fish processors, commercial fishers, independent fishers, and indigenous (native American) communities; (ii) sort-out the AFA's relations to endangered species legislation (Pollock are eaten by the at-risk Stellar sea lion); and (iii) also sort-out how pollock fishery rules would impact on other Alaskan fisheries, such as crab. In short, Mansfield shows that the neoliberalization of the pollock fishery involved as much (if not more) state regulation than previously. The conclusion appears paradoxical - 'the market' is both created and regulated by the state. It suggests that, in Mansfield's view, neoliberalisation is not about the state 'stepping-aside' but, rather, the state changing its role to actively ensure markets 'work' where they might otherwise founder if left to arise 'spontaneously'. (A similarly convincing case here is provided by Bakker [2003]; see also Bailey [2007a] and Bell \& Quiggin [2008]).

2. Making markets in environmental goods, services and assets must carefully adapt to, lest it be inhibited by, biophysical obstacles

Through the 1990s many social scientists were wont to say that 'nature' is a social construction. However, research into nature's neoliberalization show that policy makers must pay very close attention indeed to the biophysical specificities of their intended targets Otherwise, their best-laid plans can come to grief: in short, nature's material properties and affordances matter and they can complicate the form and functioning of neoliberal policies. The title of Bakker's 2003 monograph, An uncooperative commodity, indicates as much. Because water is both heavy and bulky, and because the infrastructure needed to 
both purify and move it is so very expensive, it has proven almost impossible for policy makers to create direct competition between regional scale private water companies in England and Wales post-1989. As a result, policy makers and regulators have had to devise 'clever solutions' in order to simulate direct competition and prevent water companies abusing what are, de facto, the privileges attaching to natural monopolies. The resulting market is, necessarily, a far cry from the textbook model and is highly contrived - an act of political will, if you like. This is why most water privatisation schemes over the last 30 years have been at the level of one or other locality, city or region, rather than genuinely national (see Mansfield [2004a, 2004b] and Robertson [2004] for similar arguments about 'the difference that nature makes').

3. Making markets in environmental goods, services and assets must carefully adapt to, unless it can reconfigure, the prevailing socio-cultural and political economic context As I noted earlier, all plans to neoliberalise environmental goods, services or assets necessarily occur against the background of existing policies, established conventions and prevailing economic interests. As I intimated earlier, this context must either be changed or (failing that) be negotiated if neoliberal measures are to realise their self-declared ambitions. In Polanyi's terms, if one wishes to establish a 'market economy' then one needs to alter the moral, cultural and political climate (i.e. make a 'market society' in which neoliberal norms become the prevailing common sense of the day). This is why several analysts of nature's neoliberalisation have seen fit to use Antonio Gramsci's ideas when analysing the way that neoliberal environmental policies have (or have not) 'taken hold'. Consent, after all, must be constructed - it is never sudden or spontaneously achieved.

An example of where neoliberal environmental policies have encountered relatively little communal or public opposition is presented by Wendy Wolford $(2005,2007)$. She focuses on the national land reform programme in Brazil, led by President Fernando Cardoso in the mid-90s. This programme offered many rural landless workers the possibility of owning and working their own land - this is the context of a long history of large landowners controlling a disproportionate amount of rural space. As Wolford explains, even though members of the Movement for Landless Workers (MLW) had a very different understanding of the role of land and property than did agrarian elites, many supported the Cardoso programme because it seemed to promise a degree of justice (via the language of 'rights') and the prospect of improved livelihoods. In other words, the language of reform could be made consistent with the moral economy of many MLW participants.

By contrast, Tom Perreault's $(2006,2008)$ research examines why neoliberal environmental policy failed the test of popular legitimacy in Bolivia. As indicated earlier, he focuses on the now famous 'water' and 'gas' 
wars of 2000 and 2003 respectively. In the former case especially, neoliberal reform triggered widespread protest (especially among peasant farmers) in which historic norms and cultural values were crystallised into a powerful antineoliberal discourse. Quite aside from the fact that the water reforms were antithetical to these established norms and values, both water and gas were basic resources (thus critical to many people's well-being) and seen in Bolivia as very much national resources that ought to be shared fairly not appropriated privately.

Clearly, in any given case the precise mix of factors determining the relative degree of traction and longevity of neoliberal environmental policies will vary. In cases where a fair bit of policy adaptation has occurred - in metaphorical terms, rebuilding some rooms in order to spare the foundations - the gap between the ideals of the neoliberal worldview and the messy specifics of practice become manifest (see also Bakker, 2005).

\section{Neoliberal environmental policy is, often and in large measure, constitutively 'impure'}

In the first part of this essay, repeated Peck and Tickell's argument that what we call 'neoliberalism' is a spatio-temporally differentiated process not a globally homogenous thing: a set of connected neoliberalizations, in the plural. Building on the previous point above, some have suggested that this insight applies as much to environmental management, regulation and governance as to anything else. Both Mansfield (e.g. 2007b, 2007c) and James McCarthy (2006) have been especially vocal in this regard. As part of her extensive researches into the enclosure of north Pacific fisheries, Mansfield has looked closely at how catch quotas are allocated in practice. As marketable right to fish, the quotas have commanded considerable economic value since their creation in the late 1990s. They have included a so-called 'community development quota' (CDQ) for the poor, mostly indigenous communities of Western Alaska. Within the neoliberal logic of privatisation and marketization, the CDQ addresses issues of both social justice (as an anti-poverty measure) and cultural justice (as a recognition of, and partial redress for, indigenous people's historic exclusion from land and water courtesy of European occupancy of North America). As Mansfield (ibid. 495) concludes, "What is interesting about the CDQ ... is not that it is incoherent or inconsistent, but that ... privatization [here] manages to bridge seemingly contradictory goals", namely enhancing personal (in this case communal) freedom while redistributing wealth to favour the needy.

The wider point, when points two and three above are connected to four, is that "neoliberalism ... is something created in practice, and that through practice it becomes varied, fractured and even contradictory. In this sense, 'neoliberalism' is inherently geographical ..." (Mansfield, 2004a: 580, emphasis added). In his analysis of community forestry projects, McCarthy concurs. "Processes of neoliberalization", he observes, "never occur on blank slates, but rather hybridize with existing institutions, regionally and nationally specific 
policy ensembles, and so on in ways that always and inevitably produce unique, contingent variants" (op. cit. 87). This is why empirical research is so important, and why blanket descriptions, explanations or evaluations are likely to founder on the shoals of spatio-temporal difference.

\section{Neoliberal environmental policy frequently tends to disadvantage the poor and the powerless}

As detailed in the previous section, this fifth insight is evident in Bakker's (2003) work, Budd's (2007) study of Chilean peasant irrigators, Prudham's (2004) Walkerton study, McCarthy's (2004) analysis of regulatory takings, Smith's (2004) Cape Town water resource study, and several others besides - including Tad Mutersbaugh's $(2005,2003)$ investigations of small Mexican farmers. Buscher's (2010a, 2010b) research on trans-frontier conservation likewise suggests that local communities tend to lose-out. And, where neoliberal policies appear to offer openings for the socially disadvantaged (as described in Wolford's [2005] Brazil research), there is evidence that these openings are more apparent than real. However, as noted earlier, there are exceptions to this very rough rule depending on how analysts chose to define and measure 'disadvantage'.

\section{Neoliberal environmental policy produces environmental improvements as much as} problems, and problems as much as improvements Again, this point was detailed in the previous sections. It challenges the argument that applying neoliberal principles to natural resource management and environmental problems is usually an effective way to 'green' capitalism. Quite how fundamental that challenge is remains a subject for discussion. For critics, the question is whether the improvements in environmental quality or protection delivered by certain neoliberal policy measures could have been - or be - delivered by alternative, non-neoliberal policy devices. The question is also how consistent such measures are with the achievement of social justice. Regardless, it is clear that neoliberal environmental policies can deliver certain benefits for nature, depending on the circumstances. Bakker's research on water quality shows this, so too Duffy and Moore's research into elephant tourism.

What light do these six summary observations shed on the questions I posed in section III? There, you will recall, I contrasted the political economic approach to nature's neoliberalisation favoured by many of the authors whose work I've reviewed here to a more Foucauldian approach. The former approach focuses our attention on whether the 'neoliberalization of nature' constitutes (i) a widening or deepening of class-based social power, (ii) a perpetuation, mitigation or even overcoming of the 'ecological contradictions' characteristic of capitalism to-date, and (iii) a 'winning over' of the various constituencies with a stake in the reform of resource and environmental regulation and use. These are grand questions. There is no satisfactory way to 'sum' the findings of the studies reviewed in this essay in order to provide 
robust answers to any of them. What we can say is that there is plenty of evidence now to suggest that (i) neoliberal environmental policy respects the rights of owner-operators above those of other stakeholders, (ii) does something, but not nearly enough, to address the ecologically destructive and wasteful patterns of capital accumulation, and (iii) frequently coopts people into its rationalities, but not always - and often unwillingly. The neoliberalisation of nature is a far from complete and, perhaps, precarious project.

\section{Researching nature's neoliberalization: problems of conceptualisation, theory, method and evaluation}

Are any of the six lessons identified above very definite or interesting? One would like to think so. However, as the previous paragraph intimated, there may be reasons why a critical examination of the research literature is warranted. There are, it seems to me, two forms such an examination could take. The first would focus on some rather obvious, but nonetheless important, limitations of the studies conducted so far. For instance, one might ask for a more balance in the number studies focussed on the three fields where neoliberal ideas and practices have environmental and resource content and implications. Alternatively, one might ask for a greater number of studies in a wider range of places, with a better sectoral balance so that (say) water resource issues are not favoured over investigations of (say) mining. Despite the large number of published studies into nature's neoliberalization, there are arguably not nearly enough when compared to the sheer number and variety of policy experiments one could investigate. A second form of critique would, less superficially, focus on some fundamental cognitive and normative questions that speak to the way researchers are conceiving and executing their research projects. It is this second tack I want to take because I believe there are several key issues to consider that warrant serious attention. These issues speak to the (perhaps unconscious) analytical habits of the loose, multi-disciplinary 'epistemic community' whose research I have been reviewing.

The first relates to how 'neoliberalism' is defined and conceptualised in any given empirical case. In section II, I noted - but then bracketed - the lack of conceptual consensus among analysts about the meaning of the term neoliberalism. Opening the brackets, it is clear that different investigators have employed the word in a range of ways when examining environmental and resource issues. Some authors use very generic or highly implicit definitions (e.g. Kay [2002] and Murray [2002]) that are fairly devoid of conceptual substance. Others (e.g. McCarthy, 2006) are conceptually precise, yet define the term in a way that does not quite correspond with the equally precise definitions employed by others (e.g. Robertson, 2004). Throughout, there is no real agreement about which (or how many) of the seven things listed in section II as the neoliberal policy programme need to be evident or implemented in any given case for us to reasonably describe the case as 'neoliberal' in degree or kind. 
This is unfortunate. ${ }^{26}$ For instance, should moves towards privatization alone be deemed instances of neoliberalism in action? And is what we call 'privatization' in one place really the same as that in another? Surely the meaning and significance of any one of the seven things listed earlier depends entirely on the context in which they are embedded and operate. In this sense, conceptual abstraction is a fraught process.

This last observation directs our attention to what 'context' means in any given case, and the related question of how we recognise different modalities or variants of 'neoliberalism' - that is to say, related but different neoliberalizations. As I have intimated, the sheer presence of one of more of the seven policy elements itemised in section II does not necessarily mean that it/they is or are a definitive element(s) of the situation in which it/they is/are enacted. Becky Mansfield (2007b\&c) rightly points to the constitutive 'impurity' of all neoliberal environmental measures (see also Sugden, 2009). But the researchers whose work I've surveyed have yet to separate conceptual from empirical impurity. It is little surprise that there are detailed variations in the way neoliberal environmental policies have been implemented in different times and places. The more exacting task is to identify conceptually varieties of neoliberalism by abstracting from some of the concrete empirical details. Otherwise, we are left with empirical variation alone, meaning that each and every situation in which neoliberal policy measures are implemented is considered a specific and unique 'neoliberalization'. This then greatly limits the potential for cross-case comparison and the identification of commonalities between different sets of cases. Indeed, it risks falling into the trap of 'idiography' - that is, the study of spatio-temporal difference for its own sake, at the expense of identifying common processes and outcomes across space and over time (see Castree, 2005). I recommend Karen Bakker's (2010a) most recent paper here, because she makes a serious attempt to provide a vocabulary for undertaking single-site and comparative studies.

If there is currently no agreed definition of 'neoliberalism' among analysts, those researchers whose work I have reviewed here also utilise a range of theoretical lenses when examining environmental and resource policy. Though all are critical political economists, in the general sense of that term, attempts to achieve greater theoretical consistency have been rather limited thus far. I use the term 'theory' in a conventional sense to denote a descriptive and explanatory framework that focuses the researcher on what they presume to be the most salient processes, relationships or issues in any given case. For instance, Mansfield has made ample use of Polanyi's concept of a 'fictitious commodity' in her fisheries research, while McCarthy (2004) deploys James O'Connor's Marxist notion of the 'underproduction of the conditions of production'. My colleague Erik Swyngedouw (2005), to take one more case, uses

${ }^{26}$ According to Clive Barnett (2009) it is symptomatic of 'neoliberalism's' role as a shibboleth for the Left, its value being more symbolic than analytical. 
David Harvey's concept of 'accumulation by dispossession' to discuss water resource privatisation. There are several other examples I could cite. The challenge, it seems to me, is to weave some of this otherwise disparate use of political economic theory together into a more coherent framework, one that can sensitize us to the complex, contradictory and dialectical dynamics of neoliberal environmental and resource governance in practice. Currently, what seems to happen is that any given researcher utilises a theoretical insight or idea draw from one or other of their favoured thinkers. Thus, one rarely finds a research project that integrates critically the ideas of (say) Gramsci and Polanyi, or (say) O'Connor and Gramsci. ${ }^{27}$

A third key issue I wish to highlight is methodological. When I say issue, I really mean a family of issues in the plural. Social scientists, whether they focus on human-environment relations or anything else, must typically deal with 'open systems' in which it is virtually impossible to exert 'experimental control'. Given this, they are faced with a large number of methodological choices and options. These choices and options relate to the quality and quantity of evidence, the methods of data acquisition and analysis, and the scale of methodological resolution (micro-, meso- or macro-scale?). They also involve decisions about what evidence or data to include and exclude, how it is coded and categorized, and which questions will (and will not) be asked. Inevitably, all research projects are tailored to the specific opportunities and constraints operative in any given case, even as analysts aim for rigour and systematicity. In respect of the literature reviewed in this essay, what is striking is the sheer multiplicity of ways in which the neoliberalization of nature has been investigated. In many cases, it is not even clear how - methodologically speaking - the research was conducted or quite why it was done in the way it was. The question arises: does this reflect the specifics of the situations being investigated (i.e. necessary compromises and adjustments), or is it a contingent reflection of investigators' varied expertise, time availability, level of experience, energy, commitment etc.? Regardless, the upshot is that it is very difficult indeed for readers of the research to identify methodological consistency between disparate studies. I am not so naivve as to expect, or wish for, more researchers to use the same, fairly detailed 'methodological template'. However, it is difficult to combine the insights offered by diverse studies when those studies have been conducted so very differently. It is not simply an issue of having to somehow commensurate very different kinds of evidence; there is also the issue of how robust and comprehensive the evidence from different research projects really is.

One specific methodological concern worth highlighting relates to comparative research. Thus far, there has been virtually no attempt made to investigate two or more cases of nature's neoliberalization simultaneously. This is a pity because, in theory at least, it could help us to determine with some

${ }^{27}$ For a rather abstract attempt to synthesise some of the different theoretical ideas that have been used in the literature see Castree (2008a). See Bakker (2009) for a constructive critique of this essay. 
precision what a 'variety' or 'modality' of 'actually existing neoliberalism' looks like (linking back to my point above about how analysts have defined neoliberalism). One could look at two or more situations where the same translocal (or transnational) policy measures have been implemented; or one could look at two or more cases of sui generis environmental policy that appear to be ostensibly similar (or very different) cases of neoliberal reform. James McCarthy (2006) is almost alone in having tried to conduct a cross-case study and in my view has set a precedent that ought to inspire others (see also Bailey, 2007b, and Duffy \& Moore, 2010). One methodological virtue of comparative research is that it is incumbent upon the investigator to ensure a certain consistency in the questions posed, the methods used and the evidence garnered.

Finally, let me voice some normative concerns about the way that research into nature's neoliberalization has thus far been conducted. To be a 'critic' of anything presumes that one not only has clear criteria against which that criticised is being measured, but that one can flesh-out and justify those criteria in a moral-ethical sense. As I have said, 'neoliberalism' is very much a term of the academic and activist arms of the political Left. Those who have researched nature's neoliberalization are thus in some sense sceptical about, or even opposed to, their objects of analysis. But on what grounds and in what ways? The answer to that question is surprisingly difficult to decipher because, for the most part, the act of evaluation is left implicit by those whose work I've reviewed in the preceding pages. ${ }^{28}$ In my view, they need to be made far more explicit. What is more, the grounds on which any evaluation is undertaken need to be fleshed-out in reasonable detail and, additionally, justified - no simple matter. As Andrew Sayer (1995) noted many years ago, social scientists typically devote far more of their energy to issues of theory and method than they do to issues of normative reasoning. That is certainly true of those whose work I have examined here.

The exceptions prove the proverbial rule. Mansfield's (2006) highly normative essay on the success/failure of north Pacific fisheries policy is a form of internal (or immanent) critique. In other words, she holds marked-based fisheries policy to its own evaluative criteria to provide a systematic assessment of how its performance to-date should be judged. This is one example of what could (and arguably should) be a wider effort to evaluate neoliberal environment policy by focussing on whether GEDDS (see p. 16 above) is a myth or reality. But there is another form of evaluation that has not yet been employed in a formal and explicit way in research on nature's neoliberalisation, namely 'external critique'. Here the critic evaluates the world using criteria and related moral-ethical arguments that are intentionally different from those contained within the object of analysis (contra immanent critique). Bakker's (2010b) new

\footnotetext{
${ }^{28}$ For instance, Jessica Budd's (2004) paper on Chilean water reform makes use of the concept of 'social equity' but nowhere details or defends this normative idea.
} 
book Privatizing $W$ ater hints at this alternative form of assessment. Her assessment of water resource markets rests, not uncritically, on the idea of water as a human right. Though the concept of a 'right' is central to the neoliberal worldview, Bakker reminds us that it as a far more expansive and complex idea than liberals would have us believe. It can speak to issues of social justice and resource redistribution to the needy and vulnerable, as much as to issues of individual sovereignty.

The utility of explicit and robust forms of normative assessment is clear. They are a potentially powerful weapon to use against the authors and advocates of neoliberal forms of environment management, regulation and governance. But they also keep critics honest, obliging them to acknowledge those situations where the ostensible object of their animus can be credited with certain successes.

\section{Conclusions}

This essay has comprised multi-disciplinary review of social scientific research into the 'neoliberalisation of nature', possibly the most inclusive to date. ${ }^{29}$ Reviews like this one organise and codify research that is developing organically over time, in this case in more than one academic field. The published research is the raw material out of which the survey is actively fashioned. But the cognitive mapping exercise is by no means easy. In the present case, it is not possible to begin with an agreed understanding of 'neoliberalism' evident within the literature (let alone a coherent theoretical approach to it), and then straightforwardly track neoliberalism's operation and effects in the fields of environmental management and natural resource governance. Instead, the published literature has examined different aspects of nature's neoliberalization in different times and places, and at different scales of analytical resolution. As Liverman and Vilas note in a previous attempt to review work on nature's neoliberalization systematically, "Most studies tend to be case specific and difficult to generalize" and there has been a lack of "comparative research ... set within a rigorous apriori framework" (2006: 358). I have therefore tried to throw a rope around the disparate studies, in the hope of making them make some overall sense. In so doing, I have made an admittedly contrived distinction between the process and outcomes of neoliberal policy reform in the environmental domain. Inevitably, I have also organised the insights of the studies into other analytical boxes that may, in the end, be too neat and tidy to be either useful or plausible.

Let me close with what might seem to be a very self-serving observation - though it is meant sincerely, and relates to Liverman and Vilas's candid reflection on their own attempt to author a robust review. In my experience, surveys of established or new fields of research are sometimes regarded as

${ }^{29}$ Leila Harris (2009) has recently published a useful review, focussing specifically on the gender dimensions of neoliberal environmental policy. 
'lesser outputs', academically speaking, compared to works of original empirical research or fundamental contributions to philosophy, theory or method. This is unfortunate. As I tried to show in the previous section, surveying a research field is not about piecing together a jigsaw whose parts happen to be scattered hither and thither, so that the bigger picture eventually becomes clear - even though it's often assumed to be the case. Just because a plethora of researchers use the same keywords and core concepts, it does not mean that they are - upon close inspection - actually analysing or evaluating the same thing, let alone in a theoretically or methodologically consistent or commensurable way. In the present case, one can suggest that the nominal commonality of the work I've surveyed belies a set of serious substantive differences that are variously conceptual, theoretical, methodological and normative in kind. Some might say these differences are productive, though surely not if the differences are so significant that they threaten to prevent meaningful advances in research.

What is to be done? Many decades ago, the historian of science Thomas Kuhn popularised the term 'paradigm' to characterise the working habits and outputs of a set of like-minded researchers. Perhaps those investigating nature's neoliberalisation have not been paradigmatic enough, and need to be much more so in the future. Indeed, this suggestion might apply to a great deal of contemporary social science, which is resolutely 'post-paradigmatic' for the most part (economics being a notable exception). Topics like 'neoliberalism' bring disparate researchers from various disciplines together to interrogate what is ostensibly the same thing. However, they also make plain the quantitative and qualitative variations in the way social scientific research gets conducted. Perhaps there is no way to change this state of affairs. But, looking ahead, it would surely pay dividends to aim for greater analytical consistency between otherwise different researchers operating in different academic disciplines. There is hard mental labour to be performed, but it has very practical - not purely cerebral - implications. The sorts of policy measures that analysts of nature's neoliberalization have been concerned with are rarely trivial in their effects, for good or ill. A more joined-up and less piece-meal effort by social scientists to examine these and future policy measures could have a positive and very material bearing on the well-being of people and the non-human world. Ideally, their research should actively shape the thinking of the politicians and policy makers whose decisions affect so many of our lives in so many different registers.

\section{Acknowledgements}

I am extremely grateful to Dan Brockington and Paige West for permitting me to write at such length on nature's neoliberalisation. I also wish to thank the four reviewers of this paper who took considerable time and trouble to offer me superb evaluations of the first draft. One of the two anonymous reviewers posed some especially sharp and challenging questions which I dearly wanted to respond to when revising the essay. However, for reasons beyond my control, I had very little time indeed to alter the paper and so the published version is for better or worse - similar to the original version. This said, I hope I have now knitted 
together the essay's various parts so as to address at least one concern expressed by the most critical of the four reviewers. As ever, I take full credit for the essay's various flaws.

\section{Bibliography}

Anderson, P. (2000) 'Renewals', New Left Review 1, January-February:

Antipode (2010) Special issue on 'Capitalism and conservation', 42, 3: 469-799.

Bakker, K. (2001) 'Paying for water', Transactions of the Institute of British

Geographers 26, 2: 143-64.

Bakker, K. (2003) An uncooperative commodity: Privatizing water in England and Wales.

Oxford: Oxford University Press.

Bakker, K. (2005) 'Neoliberalizing nature? Market environmentalism in water supply in England and Wales', Annals of the Association of American Geographers 95, 3: 542-65.

Bakker, K. (2009) 'Neoliberal nature, ecological fixes and the pitfalls of comparative research', Environment and Planning A 41, 9: 1481-87.

Bakker, K. (2010a) 'The limits of "neoliberal nature": debating green neoliberalism', Progress in Human Geography, forthcoming.

Bakker, K. (2010b) Privatizing water. Ithaca: Cornell University Press.

Bailey, I. (2007a) 'Neoliberalism, climate governance and the scalar politics of EU emissions trading', Area 39, 4: 431-42.

Bailey, I. (2007b) 'Market environmentalism, new environmental policy instruments, and climate policy in the UK and Germany', Annals of the Association of American Geographers 97, 3: 530-50.

Barnett, C. (2005) 'The consolations of neoliberalism', Geoforum 36, 1: 7-12. Barnett, C. (2009) 'Publics and markets: what's wrong with neoliberalism?', in S. Smith et al. (eds) Handbook of Social Geographies (London: Sage) pp. ??.

Barry, Osborne, P. and Rose, N. (1996) Foucault and political reason

liberalism, neo-liberalism, and rationalities of government (Chicago: University of Chicago Press).

Bell, S. and Quiggin, J. (2008) 'The limits of markets: the politics of water management in rural Australia', Environmental Politics 17, 5: 712-29.

Bernstein, S. (2002) 'Liberal environmentalism and global environmental governance', Global Environmental Politics 2, 3: 1-16.

Boas, T. and Gans-Morse, J. (2009) 'Neoliberalism: from new liberal philosophy to anti-liberal slogan', Studies in Comparative International Development 44, 2: 137-61. Brand, U. and Sekler, (2009) Special issue on 'Postneoliberalism?', Development Dialogue 51, January.

Brenner, N. and Theodore, N. (2002) 'Cities and the geographies of 'actually existing neoliberalism", Antipode 34, 3: 349-79.

Brenner, N., Peck, J. and Theodore, N. (2010) 'After neoliberalization?', Globalizations 7, 3: 327-45.

Bridge, G. (2002) 'Grounding globalization', Economic Geography 78, 3: 361-86. Brown, S. and Getz, C. (2008) 'Privatizing farm worker justice: regulating labor through voluntary certification and labeling', Geoforum 39, 3: 1184-96. 
Budds, J. (2004) 'Power, nature and neoliberalism: the political ecology of water in Chile', Singapore Journal of Tropical Geography 25, 3: 322-42.

Bury, J. (2004) 'Livelihoods in transition: transnational gold mining operations and local change in Cajamarca, Peru', The Geographical Journal 170, 1: 78-91.

Bury, J. (2005) 'Mining mountains: neoliberalism, land tenure, livelihoods, and the new Peruvian mining industry in Cajamarca', Environment and Planning A 37, 2: 221-40.

Buscher, B. (2010a) 'Seeking 'telos' in the transfroniter?' Environment and Planning A 42, 3: 644-60.

Buscher, B. (2010b) 'Anti-politics as political strategy: neoliberalism and transfrontier conservation in southern Africa', Development \& Change 41, 1: 29-51. Buscher et al. (2011) 'towards a consolidated critique of neoliberal biodiversity conservation', Capitalism, Nature, Socialism 22, 4.

Buscher, B. and Dressler, W. (2007) 'Linking neoprotectionism and environmental governance: on the rapidly increasing tensions between actors in the environment-development nexus', Conservation \& Society 5, 4: 586-602. Capitalism, Nature, Socialism (2005) Special issue on 'The commodification of nature' $16,1$.

Castree, N. (2005) 'The epistemology of particulars', Geoforum 36, 4: 541-44.

Castree, N. (2008a) 'Neoliberalising nature: the logics of deregulation and reregulation', Environment and Planning A 40, 1: 131-52.

Castree, N. (2008b) 'Neoliberalising nature: processes, outcomes and effects', Environment and Planning A 40, 1: 153-73.

Castree, N. (2010a) 'Neoliberalism and the biophysical environment 1: what 'neoliberalism' is, and what differen nature makes to it', Geography Compass 4/12 (2010): 1725-1733.

Castree, N. (2010b) Neoliberalism and the biophysical environment 2: theorising the neoliberalisation of nature', Geography Compass 4/12: 1734-46. Castree, N. (2010c) 'Neoliberalism and the biophysical environment 3: putting theory into practice', Geography Compass 4/12: 1747-66.

Clarke, J. (2004) 'Dissolving the public realm?', Journal of Social Policy 33, 1: 27-48. Clarke, J. (2010) 'After neoliberalism?', Cultural Studies 24, 3: 375-94.

Cocklin, C., Dibden, J. and Mautner, N (2006) 'From market to multifunctionality?', Geographical Journal 172, 3: 197-205.

Coombes, B. (2003) 'Ecospatial outcomes of neoliberal planning', Environment and Planning B 30, 2: 201-18.

Craig, D. and Cotterell, G. (2007) 'Periodising neoliberalism?', Policy \& Politics 35, 3: 497-514.

Crouch, C. (2004) 'Markets and states', in K. Nash and A. Scott (eds) The Blackwell Companion to Political Sociology (Oxford: Blackwell) pp. 240-50.

Davis, D. (2006) 'Neoliberalism, environmentalism, and agricultural restructuring in Morocco', Geographical Journal 172, 2: 88-105.

Dibden, J., Potter, C. and Cocklin, C. (2009) 'Contesting the neoliberal project for agriculture', Journal of Rural Studies 25, 3: 299-308. 
Driesen, D. (2008) 'Sustainable development and market liberalism's shotgun wedding', Indiana Law Journal 83, 21: 21-69.

Duffy, R. (2008) 'Neoliberalising nature: global networks and ecotourist development in Madagascar', Journal of Sustainable Tourism 16, 3: 327-344. Duffy, R. and Moore, L. (2010) 'Neoliberalising nature? Elephant-back tourism in Thailand and Botswana', Antipode 42, 3: 742-66.

Eckersley, R. (1993) 'Free market environmentalism: friend or foe?', Environmental Politics 2, 1: 1-19.

England, K. and Ward, K. (eds) (2007) Neoliberalization (Oxford: WileyBlackwell).

Ferguson, J. (2010) 'The uses of neoliberalism', Antipode 42, S1: 166-84. Fletcher, R. (2011) 'Neoliberal governmentality: towards a poststructural political ecology of the conservation debate, Conservation and Society 9, 1:

Fortwangler, L. (2007) 'Friends with money: private support for a national park in the US Virgin Islands', Conservation \& Society 5, 4: 504-33.

Fraser, N. (1993) 'Clintonism, welfare and the anti-social wage: the emergence of a neoliberal political imaginary', Rethinking Marxism 6, 1: 9-23.

Friedman, M. (1962) Capitalism and freedom

Geoforum (2004) Special issue on 'Neoliberal nature and the nature of neoliberalism', 35, 3.

Goldman, M. (2005) Imperial nature (New Haven: Yale University Press). Gordon, H. S. (1954) 'The economic theory of a common property resource: the fishery', Journal of Political Economy 62: 124-42.

Gowan, P. (1995) 'Neoliberal theory and practice for eastern Europe', New Left Review 123:

Grandia, L. (2007) 'Between Bolivar and bureaucracy: the Mesoamerican Biological Corridor', Conservation \& Society 5, 4: 478-503

Guthman, J. (2007) 'The Polanyian way? Voluntary food labels as neoliberal governance', Antipode, 39, 3: 456-79.

Guthman, J. (ed.) (2008a) 'Agro-food activism in California and the politics of the possible', special section of Geoforum 39, 3: 1171-1260.

Guthman, J. (2008b) 'Neoliberalism and the making of food politics in California', Geoforum 39, 3: 1171-83.

Guthman, J. (2008c) 'Thinking inside the neoliberal box: the micro-politics of agro-food philanthropy', Geoforum 39, 3: 1241-53.

Haggerty, J., Campbell, H. \& Morris, C. (2009) 'Keeping the stress off the sheep? Agricultural intensification, neoliberalism and "good" framing', Geoforum 40, 4: 767-77.

Hardin, G. (1968) 'The tragedy of the commons', Science 162, 1243-1248.

Hardin, G. (1974) 'Living on a lifeboat', Bioscience 24, 561-568.

Harrison, J. (2008) 'Pesticide drift activism and the contestation of neoliberal environmental politics in California', Geoforum 39, 3: 1197-1214.

Harris, L. (2009) 'Gender and emergent water governance', Gender, Place \& Culture 16, 4: 387-408. 
Hartwick, E. and Peet, R. (2003) 'Neoliberalism and nature: the case of the WTO', The Annals of the American Academy of Political \& Social Science 590, November: 188-211.

Harvey, D. (2005) A brief history of neoliberalism (Oxford: Oxford University Press).

Harvey, D. (2007) 'Neoliberalism as creative destruction', Annals of the American Academy of Political and Social Science 610, March: 22-44.

Heynen, N. \& Perkins, H. (2005) 'Scalar dialectics in green: urban private property and the contradictions of the neoliberalization of nature', Capitalism, Nature, Socialism 16, 1: 5- 18.

Heynen, N., McCarthy, J., Prudham, S. and Robbins, P. (eds) (2007) Neoliberal environments (London: Routledge).

Higgins, V. and Lockie, S. (2002) 'Rediscovering the social: neoliberalism and hybrid practices of governing in rural natural resource management', Journal of Rural Studies 18, 3: 419-28.

Himley, M. (2008) 'Geographies of environmental governance: the nexus of nature and neoliberalism', Geography Compass 2: 433-51.

Ibarra, A., Reid, C. and Thorpe, A. (2000) 'Neoliberalism and its impact on overfishing and overcapitalisation in the marine fisheries of Chile, Mexico and Peru', Food Policy 25, 4: 599-622.

Igoe, J. and Brockington, D. (2007) 'Neoliberal conservation: a brief overview', Conservation and Society 5, 4: 432-49.

Igoe, J. and Croucher, B. (2007) 'Conservation, commerce, and communities: the story of community-based wildlife management areas in Tanzania's northern tourist circuit', Conservation \& Society 5, 4: 534-61.

Holified, R. (2004) Neoliberalism and environmental justice in the US Environmental Protection Agency', Geoforum 35, 3: 285-98.

Kay, C. (2002) 'Chile's neoliberal agrarian transformation and the peasantry', Journal of Agrarian Change 2, 4: 464-501.

Kingfisher, C. and Maskovsky, J. (2008) 'The limits of neoliberalism', Critique of Anthropology 28, 2: 115-26.

Larner, W. (2003) 'Neoliberalism?', Society and Space 21, 4: 509-12.

Larner, W. (2000) 'Neoliberalism: policy, ideology, governmentality', Studies in Political Economy 63, Autumn: 2-25.

Leitner, H., Peck, J. and Sheppard, E. (eds) (2007) Contesting neoliberalism (New York: Guilford).

Levine. A. (2007) 'Staying afloat: state agencies, local communities, and international involvement in marine protected area management in Zanzibar, Tanzania', Conservation \&o Society 5, 4: 562-85.

Lockwood, M. and Davidson, J. (2009) 'Environmental governance and the hybrid regime of Australian natural resource management', Geoforum 41, 3: 38898.

Loftus, A. and Macdonald, D. (2001) 'Of liquid dreams: a political ecology of water privatization in Buenos Aires', Environment \& Urbanization 13, 2: 179-99. 
Liverman, D.M. and Vilas, S. (2006) 'Neoliberalism and the environment in Latin America', Annual Review of Environment and Resources 31, 1: 327-363.

Lovell, H. et al. (2009) 'Carbon offsetting: sustaining consumption?', Environment \& Planning A 41, 10: 2357-79.

Mansfield, B. (2004a) 'Rules of privatization: contradictions of neoliberal regulation of North Pacific fisheries', Annals of the Association of American Geographers 94, 3: 565-84.

Mansfield, B. (2004b) 'Neoliberalism in the oceans: "rationalization", property rights and the commons question', Geoforum 35, 3: 313-26.

Mansfield, B. (2006) 'Assessing market-based environmental policy using a case study of north Pacific fisheries', Global Environmental Change 16, 1: 29-39. Mansfield, B. (ed.) (2007a) Privatization: property and the remaking of society-nature relations (Oxford: Wiley-Blackwell).

Mansfield, B. (2007b) 'Property, markets and dispossession: the Western Alaska community development quota as neoliberalism, social justice, both or neither', Antipode 39, 3: 479-99.

Mansfield, B. (2007c) 'Articulation between neoliberal and state-oriented environmental regulation: fisheries privatization and endangered species protection', Environment and Planning A 39, 12: 1926-1942.

McCarthy, J. and Prudham, S. (2004) Neoliberal nature and the nature of neoliberalism', Geoforum 35, 3: 275-283.

McCarthy, J. (2004) 'Privatizing the conditions of production', Geoforum 35, 3: $327-41$.

McCarthy, J. (2006) 'Neoliberalism and the politics of alternatives', Annals of the Association of American Geographers 96, 1: 84-104.

Mirowski, P. and Plehwe, D. (eds) (2008) The making of the neoliberal thought collective (Cambridge, Mass: Harvard University Press).

Morris. A. (2008) 'Easing conservation? Conservation easements, public accountability and neoliberalism', Geoforum 39, 3: 1215-27.

Mudge, S. (2008) 'What is neoliberalism?', Socio-Economic Review 6, 4: 703-31.

Murray, W. (2002) 'The neoliberal inheritance: agrarian policy and rural differentiation in Democratic Chile', Bulletin of Latin American Research 21, 3: 42541.

Mutersbaugh T, (2003) 'Ethical trade and certified organic coffee: the implications of agricultural product certification for Mexican producer households and villages', Transnational Law and Contemporary Problems 12, 1: 89107.

Mutersbaugh T. (2005) 'Fighting standards with standards: harmonization, rents, and social accountability in certified agrofood networks', Environment and Planning A 37, 11: 2033-2051

Nickson, A. and Vargas, C. (2002) 'The limitations of water regulation', Bulletin of Latin American Research 21, 1: 128-49. 
Pearson, T. (2009) 'On the trail of living modified organisms: environmentalism within and against the neoliberal order', Cultural Anthropology 24, 4: $712-45$.

Peck, J. (2006) 'Countering neoliberalism', Urban Geography 27, 8: 729-33.

Peck, J. (2008) 'Remaking laissez faire', Progress in Human Geography 32, 1: 3-43. Peck, J. and Tickell, A. (2002) 'Neoliberalizing space', Antipode 34, 3: 380-404. Perkins, H. (2009) 'Out of the (green) shadow? Neoliberal hegemony through the market logic of shared urban governance', Geoforum 28, 3: 395-405.

Perreault, T. (2005) 'State restructuring and the scale politics of rural water governance in Bolivia', Environment and Planning A 37, 2: 263-84.

Perreault, T. (2006) 'From the guerra del agua to the guerra del gas', Antipode 38, 1: 150-72.

Perreault, T. (2008) 'Custom and contradiction: rural water governance and the politics of usos y costrumbres in Bolivia's irrigators' movement', Annals of the Association of American Geographers 98, 4: 834-54.

Polanyi, K. (1944) The great transformation (Boston: Basic Books).

Potter, C. (2006) 'Competing narratives for the future of EU agriculture', The Geographical Journal 172, 3: 190-96.

Pritchard, B. (2005a) 'Implementing and maintaining neoliberal agriculture in Australia part I', Journal of the Sociology of Agriculture 13, 1: 1-12.

Pritchard, B. (2005b) 'Implementing and maintaining neoliberal agriculture in Australia part II', Journal of the Sociology of Agriculture 13, 2: 1-14.

Prudham, S. (2004) 'Poisoning the well: neoliberalism and the contamination of municipal water in Walkerton, Ontario', Geoforum 35, 3: 343-60.

Prudham, S. (2007) 'The fictions of autonomous invention: accumulation by dispossession, commodification and life patents in Canada', Antipode 39, 3: 40629.

Prudham, S. and Morris, A. (2006) 'Making the market "safe" for GM foods', Studies in Political Economy 78, Autumn: 145-75.

Review of Radical Political Economics (2010) Special issue on the political economy of water privatization, 42, 2.

Robbins, P. and Luginbuhl, A. (2005) 'The last enclosure', Capitalism, Nature, Socialism 16, 1: 45-61.

Roberts, A. (2008) 'Privatising social reproduction: the primitive accumulation of water in an age of neoliberalism', Antipode 40, 4: 535-60.

Robertson, M. (2004) 'The neoliberalization of ecosystem services', Geoforum 35, 3: 361-74.

Robertson, M. (2006) 'The nature that capital can see: science, state and market in the commodification of ecosystem services' Environment and Planning D: Society and Space 24, 3: 367-387.

Robertson, M. (2007) 'Discovering price in all the wrong places: the work of commodity definition and price under neoliberal environmental policy', Antipode 39, 3: 500-26. 
Rodriguez, M. G. M. (2003) 'Privatization and socioeconomic conditions in Brazil's Amazonia: political challenges to neoliberal principles', Journal of Environment \& Development 12, 2: 205-38.

Roff, R. J. (2008) 'Preempting to nothing: neoliberalism and the fight to de/reregulate agricultural biotechnology', Geoforum 39, 6: 1423-1438.

Sangameswaran, P. (2008) 'Neoliberalism and water reforms in western India', Geoforum 40, 2: 228-38.

Sayer, A. (1995) Radical political economy (Oxford: Blackwell).

Smith, L. (2004) 'The murky waters of the second wave of neoliberalism', Geoforum 35, 3: 375-93.

St. Martin, K. (2006) 'The impact of 'community' on fisheries management in the US northeast', Geoforum 37, 2: 169-84.

St. Martin, K. (2007) 'The difference that class makes: neoliberalization and non-capitalism in the fishing industry of New England', Antipode 39, 3: 527-49. Sugden, F. (2009) 'Neoliberalism, markets and class structures in the Nepali lowlands', Geoforum 40, 5: 634-44.

Sullivan, S. (2006) 'The elephant in the room? Problematising 'new' (neoliberal) biodiversity conservation', Forum for Development Studies 1, June: 105-35.

Swyngedouw, E. (2005) 'Dispossessing $\mathrm{H}_{2} \mathrm{O}$ : the contested terrain of water privatisation', Capitalism, Nature, Socialism 16, 1: 81-98.

Tickell, A. and Peck, J. (1995) 'Social regulation after Fordism: regulation theory, neoliberalism and the local-global nexus', Economy and Society 24, 3: 357-86.

Valdivia, G. (2004) 'On indigeneity, change, and representation in the northeastern Ecuadorian Amazon', Environment and Planning A 37, 2: 285-302.

von Hayek, F. (1944) The road to serfdom von Hayek, F. (1960) The Constitution of Liberty Watkins, S. (2010) 'Blue Labour?', New Left Review 63, May-June: 5-16.

West, P. (2010) 'Making the market: speciality coffee, generational pitches, and Papua New Guinea', Antipode 42, 3: 690-718.

Wilder and Lankao (2006) 'Paradoxes of decentralization: water reform and social implications in Mexico', World Development 34, 11: 1977-95.

Wilshusen, P. (2010) 'The receiving end of reform: everyday responses to neoliberlization in southeastern Mexico', Antipode 42, 3: 767-98.

Wolford, W. (2005) 'Agrarian moral economies and neoliberalism in Brazil: competing worldviews and the state in the struggle for land', Environment \& Planning A 37, 2: 241-61.

Wolford, W. (2007) 'Land reform in the time of neoliberalism', Antipode 39, 3: $550-70$. 